\title{
A etnia e a terra: notas para uma etnologia dos índios Arara (Aripuanã - MT) ${ }^{1}$
}

Resumo: Esta é uma coletânea de artigos e entrevistas sobre os índios Arara que vivem no município de Aripuanã, a noroeste do Estado de Mato Grosso. Trata-se aqui, principalmente, de passar a limpo uma certa questão que, desde que os conheço ${ }^{3}$, a eles colocam sem cessar: não seriam apenas seringueiros, apenas caboclos miscigenados, beiradeiros? Índios? Se me disponho a respondê-la, não me engano, porém, com as intenções que estão aí embutidas. Sei muito bem que não a fazem num desprendido exercício intelectual ou mera curiosidade. Não se trata, com efeito, de alguma especulação desinteressada sobre a formação étnica ou o processo histórico que caracterizou aquela população regional: os que negam a indianidade aos Arara, sem sofismas, não pretendem mais que lhes negar o direito à posse e ao usufruto das terras tradicionais.

Palavras-chave: etnia; território; povo Arara.

\footnotetext{
${ }_{1}$ Originalmente publicado na Série Antropologia n. 4, publicada pela Editora da UFMT, no ano de 1995. Reproduzido aqui com autorização da EdUFMT. Mantivemos as grafias originais.

2 Doutor em Ciências Sociais (Universidade Estadual de Campinas, 2004), mestre em Antropologia Social (Universidade de São Paulo, 1991) e graduado em Engenharia Metalúrgica (Pontifícia Universidade Católica do Rio de Janeiro, 1976). Participou de projetos e da coordenação da Operação Amazônia Nativa (1977-1993) e lecionou na Universidade Federal de Mato Grosso (1992-2005) e na Universidade Federal de Juiz de Fora (2005-2014). Como este texto foi originalmente publicado quando o autor lecionava na UFMT, mantivemos esta como sua filiação institucional.

3 Estive vinculado ao Projeto Cinta Larga, da OPAN - Operação Anchieta, uma entidade indigenista, nos anos de 1980 a 1984. No ano de 1987, desenvolvi pesquisas naquela região para fins de elaboração da dissertação de mestrado. E em 1992, fiz uma viagem ao Guariba junto com uma equipe do GERA/UFMT. A maior parte dos dados etnográficos e históricos que aqui utilizo foram se acumulando ao longo destes anos todos. Agradeço ao CIMI-MT, à OPAN e à CAIEMT a consulta aos seus arquivos, bem como aos colegas do Departamento de Antropologia/UFMT pelas sugestões recebidas.
} 


\title{
Ethnicity and the land: notes for an ethnology of Arara Indians (Aripuanã - MT)
}

\begin{abstract}
This is a collection of articles and interviews about the Arara Indians who live in the city of Aripuanã, northwest of the State of Mato Grosso. Here, it is mainly a matter of clearing up a certain question that, as long as I know them, they constantly ask themselves: wouldn't they be just rubber tappers, just miscegenated caboclos, bordering on? Indians? If I am willing to answer it, I am not mistaken, however, with the intentions that are embedded in it. I know very well that they do not do it in a detached intellectual exercise or mere curiosity. It is not, in effect, any disinterested speculation about the ethnic formation or the historical process that characterized that regional population: those who deny the Arara Indianity, without sophistry, do not intend to deny them the right to possess and enjoy traditional lands.
\end{abstract}

Keywords: ethnicity; territory; Arara people.

\section{Etnicidad y tierra: notas para una etnología de Indios Arara (Aripuanã - MT)}

\begin{abstract}
Resumen: Esta es una colección de artículos y entrevistas sobre los indios Arara que viven en el municipio de Aripuanã, al noroeste del estado de Mato Grosso. Aquí, se trata principalmente de aclarar una cierta pregunta que, siempre y cuando los conozca, se preguntan constantemente: ¿no serían simplemente recolectores de goma, solo caboclos mestiza, bordeando? ¿Indios? Sin embargo, si estoy dispuesto a responderla, no me equivoco con las intenciones que están incrustadas allí. Sé muy bien que no lo hacen en un ejercicio intelectual suelto o mera curiosidad. No es, en efecto, una especulación desinteresada sobre la formación étnica o el proceso histórico que caracterizó a la población regional: aquellos que niegan a los indios Arara, sin sofismas, no tienen la intención de negarles el derecho a poseer y disfrutar tierras tradicionales.
\end{abstract}

Palabras clave: etnicidad; territorio; pueblo Arara. 


\title{
São índios?
}

Ainda hoje se mantém o mito de que os aborígenes, nesta parte da América, limitaram-se a assistir à ocupação da terra pelos portugueses e a sofrer, passivamente, os efeitos da colonização.

Florestan Fernandes, 1975

$\mathrm{E}$ sta é uma coletânea de artigos e entrevistas sobre os índios Arara que vivem no Município de Aripuanã, a noroeste do Estado de Mato Grosso. Trata-se aqui, principalmente, de passar a limpo uma certa questão que, desde que os conheço, a eles colocam sem cessar: não seriam apenas seringueiros, apenas caboclos miscigenados, beiradeiros? Índios? Se me disponho a respondêla, não me engano, porém, com as intenções que estão aí embutidas. Sei muito bem que não a fazem num desprendido exercício intelectual ou mera curiosidade. Não se trata, com efeito, de alguma especulação desinteressada sobre a formação étnica ou o processo histórico que caracterizou aquela população regional: os que negam a indianidade aos Arara, sem sofismas, não pretendem mais que lhes negar o direito à posse e ao usufruto das terras tradicionais.

À negação, portanto, conjuga-se a obstinação sem disfarces de consolidar a apropriação e a exploração do território Arara, entre os rios Branco e Guariba. Uma campanha bem urdida que, das palavras às ações, tem cristalizado naquele município um panorama maniqueísta, onde a simples afirmação da identidade indígena é, de imediato, tomada como uma tática conspiratória dos que se oporiam ao "progresso" da região. Tal retórica pseudodesenvolvimentista tem fomentado sobremaneira as agressões verbais e físicas aos índios e seus aliados. Ilustrativo a este respeito, numa espécie de manifesto assinado pelo sr. Policarpio Mestrinho Rondon de Sá e direcionado ao senador Jonas Pinheiro, temos a posição de um autoproclamado Grupo de Defesa da Amazônia (?): "Forjaram a tribo $e$ os Índios, inventaram a aldeia e fabricaram a reserva indígena e tomaram posse usando violência, invadindo as fazendas”.

E logo adiante, uma exposição inequívoca dos motivos que orientam suas invectivas:

\begin{abstract}
A população de Aripuanã sabe que precisa urgente da estrada. Sabe que não pode continuar sendo fim de linha e coberto de reservas indígenas, ecológicas e extrativistas por todos os lados (...). Aripuanã sabe, que a BR-174 é a redenção de todo o Noroeste do Estado. (RONDON DE SÁ, 1995)
\end{abstract}

Não hei de perguntar aqui, por desnecessário, a quem serve este discurso acusatório ou mesmo acerca da concepção messiânica (e predatória) de desenvolvimento que veicula 4 . Cabe interrogar, todavia, sua realidade empírica, histórica e etnográfica. E combater, isto sim, a manipulação ideológica que faz dos conceitos e dos preconceitos esta apologia etnocêntrica do "progresso" que aqui e ali ressoa como um solerte e anacrônico neo-bandeirantismo.

Contudo devo confessar, para que fiquem assentadas as bases epistemológicas desta investigação - pois assim está colocado o problema no campo das ciências sociais, se não de todo e qualquer conhecimento - que a reflexão antropológica não se faz tampouco com o olhar vago e desinteressado. Os antropólogos,

4 Sem pretender no presente trabalho discutir a natureza dos direitos originais dos índios às terras que ocupam, basta lembrar que "os índios têm direito porque sua posse é, historicamente, anterior à fundação do Estado brasileiro", razão pela qual a Constituição de 1988 e as anteriores os acataram (cf. DAL POZ, 1995). 
definitivamente, em nada se parecem com algum desalmado colecionador de relíquias e variedades bizarras ou uma espécie acadêmica do personagem Indiana Jones. Não somente no sentido que polemicamente defendeu Darcy Ribeiro (1979), para quem a Antropologia, para não ser simplesmente inútil ou colonialista, teria como obrigação se interessar pelo destino daqueles a quem estuda. Mas fundamentalmente porque, como nos ensina Roberto Da Matta (1981), ao tomar como ponto de partida "a posição e o ponto de vista do outro", a Antropologia se realiza como um profundo exercício de comutação e de mediação, como uma experiência genuína de relativização de conceitos e de valores ${ }^{5}$. E deste ângulo, ao buscarmos significados que extrapolam nossos próprios quadros culturais, nada do que é humano pode nos deixar insensíveis, nem alheios ou descompromissados.

As descobertas antropológicas, basicamente a constatação da rica diversidade cultural que caracteriza a humanidade, têm significado, sobretudo, um aprimoramento intelectual e moral da própria civilização ocidental, notadamente porque nos permitiram vê-la como uma entre tantas outras escolhas possíveis - e por isto mesmo, sujeita a toda sorte de deslocamentos e mutações. Não há, desta perspectiva, nenhuma hierarquia absoluta, nem qualquer esquema evolutivo ou destino histórico inexorável ao qual as sociedades humanas estariam a priori vinculadas ou submetidas. Demasiadamente humanos em tudo, somos, portanto, de alguma maneira os espíritos livres - embora talvez não agradasse a Nietzsche este jeito de enunciar o porvir incessante de conceitos e de valores.

E aqui voltamos ao caso dos Arara. A rigor, a denegação da identidade étnica por seus inquisidores tem se apoiado particularmente no seguinte pressuposto: uma vez aculturados e a serviço dos seringais, os índios não seriam mais índios, pois já se civilizaram. Ao que parece, cobram destes índios, que sempre foram louvados por mansos e pacíficos, cuja propensão à civilização encantou a muitos, uma feição diferente, um modo de ser original e exótico. Å moda kafkiana, se me permitem a expressão, as mudanças sociais e culturais, que no passado foram impostas aos Arara a todo custo, estão no presente sendo arguidas como contraprovas de sua identidade. Inconvenientes antes, os costumes indígenas se tornaram, agora, indispensáveis para que os Arara não sejam declarados extintos, à sua revelia.

Uma mudança arbitrária e paradoxal nas regras do jogo? A ambiguidade é, entretanto, apenas a aparência das coisas, uma vez que o "jogo" das regras atende primordialmente às próprias "regras" da conquista civilizatória. Como neste discurso arrogante de um sociólogo da FUNAI, que tentava pressionar os Arara a desistir de suas reivindicações territoriais (entre elas a área onde está um cemitério), para quem a sujeição cultural demonstraria a condição inequívoca de povo definitivamente conquistado e dominado:

\footnotetext{
Mas vocês dizem: não, a terra foi nossa. Mas o Brasil todo foi dos índios. (...). Tem que ver isso também, gente. A lógica do branco. O branco é o vencedor, ou a gente esqueceu isso? Está na história, não adianta ignorar. Os índios foram vencidos, gente. $O$ que se faz agora é tentar resgatar esse respeito a uma cultura que tem aí. Mas os índios foram vencidos pelos brancos. Foram vencidos no sentido de perderem o domínio sobre tudo isso que está aí. Isso aí tudo era domínio dos nativos daqui. E perderam o domínio, como é que não foram vencidos? Vocês [os Arara] foram obrigados a aprender a falar português. O que é isso? Isso é uma demonstração de vencidos. Porque quem é vitorioso não tem que aprender a falar a língua de ninguém. Quem é vencido é obrigado a se adaptar ao vencedor. (apud SILVA, 1988) ${ }^{6}$
}

$5 \mathrm{O}$ que faz da Antropologia uma empreitada estimulante, como reconheceram Malinowski (1984: 34) e vários outros posto que, através da compreensão de sociedades distantes e estranhas, somos levados a entendermo-nos a nós mesmos. 6 Trecho de um pronunciamento de José Augusto Mafra dos Santos, sociólogo da FUNAI, em Aripuanã, em 23 de agosto de 1988, quando das negociações para delimitação da área indígena Arara do Rio Branco. 
De nenhuma forma elípticos, os argumentos acima desvendam antes de tudo quem os enuncia e a posição de seu autor nas relações de poder constituídas, portanto suas convicções e seu autoritarismo - analisarei isto adiante, no capítulo 2. Detenho-me a examinar, neste momento, estas outras questões que ele também suscita, cuja importância se pode aquilatar pelo grau de seu enraizamento na opinião pública mediana. Em primeiro lugar, se o fato de "aprender a falar português" (e andar vestido, usar dinheiro, possuir carro etc.) denota uma dissolução, um desaparecimento de todas e quaisquer diferenças culturais e étnicas. Segundo, se as relações entre índios e brasileiros, como há quinhentos anos, devem estar hoje e sempre determinadas pela lógica colonial, de conquista e destruição do Outro.

Começando por esta última, prefiro acreditar que não, e que a existência de tantos povos indígenas no Brasil signifique um valor positivo a nos engrandecer diante da humanidade. E vale notar a este respeito que não se conhece, em toda a tradição legislativa brasileira, qualquer referência, mesmo remota, a um suposto direito dos vencedores... Mesmo porque, veremos no capítulo que encerra esta coletânea7, a história ainda não chegou ao seu final.

Quanto à segunda questão, há que se observar, já nos dizia sabiamente LéviStrauss (1976) em seu ensaio Raça e História, que a diversidade das culturas humanas "não deve ser concebida de maneira estática", porém como uma função das relações que as sociedades mantêm umas com as outras, num perpétuo movimento de distanciamentos e de aproximações. E porque a cultura, ao contrário do que supõe o senso comum, não sendo um mero aglomerado de traços inertes, antes se traduz como um sistema sujeito a alterações em contextos mais abrangentes e plurais. E que no caso das sociedades multiétnicas, a exemplo da brasileira, as referências culturais dos grupos e segmentos sociais em disputa econômica ou política estarão continuamente sendo reelaboradas, reordenadas e mobilizadas. Não podia ser de outra forma, já que nenhuma sociedade é ou pretende ser uma ilha ou uma mônada impenetrável.

Mas se não é a cultura, alguém talvez pergunte, então o que fica, o que permanece como garantia de uma identidade indígena? Responderia com as palavras de Manuela Carneiro da Cunha (1994), para quem "pode-se entender a identidade [étnica] como sendo simplesmente a percepção de uma continuidade, de um processo, de um fluxo, em suma, uma memória”.

São estes os termos pelos quais procurei, o mais amplamente possível, inventariar os dados históricos e etnográficos existentes sobre os Arara, no sentido de rastrear e ilustrar um processo necessariamente contraditório: de início, a desarticulação social promovida pela sua inserção nos seringais; e mais recentemente, o revival étnico em torno da reconquista e retorno a seu território.

Conheci José Rodrigo e Ana Anita Vela e seus filhos em Aripuanã, em fins de 1980. Quando chegaram à cidade, expulsos do rio Branco, em condições muito ruins (alguns deles com tuberculose), foram acolhidos pela gente simples que ali vivia, com generosidade: alimentos, tábuas para construir a casa, internação hospitalar... E por uns poucos anos tentaram, neste novo ambiente, reconstruir sua vida. Algumas outras famílias Arara já moravam em Aripuanã. Mas nos anos seguintes, a estas vieram se juntar mais famílias igualmente enxotadas do beiradão do rio Aripuanã pelos latifundiários. O sonho de uma vida melhor na cidade, deles

7 O autor está se referindo ao número 4, da Série Antropologia, onde o presente artigo foi originalmente publicado. [Nota do Editor] 
e de tantos outros seringueiros, não passava de ilusão: vivendo de biscates, passando dificuldades, discriminados. Restava-lhes como alternativa lutar por seus direitos. Acompanhei este processo, às vezes mais outras vezes menos próximo, e assim fui percebendo uma certa costura sutil entre, de um lado, as lembranças de outrora e de outro, a disposição e a força de vontade que animava Anita, Rodrigo e alguns poucos. Despojados de tudo, exceto da memória e das palavras - e foi justamente em torno delas que os Arara se reuniriam para retornarem às suas terras.

No Capítulo 1 disponho as fontes e os dados sobre o relacionamento dos índios com os seringais da região. Procuro mostrar que, sob a denominação Arara, foram designados pelo menos três grupos que se acercaram dos seringueiros. No Capítulo 2 discuto os resultados de um Grupo de Trabalho da FUNAI, cuja conclusão foi que estas etnias estariam extintas e que seus remanescentes, miscigenados, aculturados e dispersos, numa fórmula deveras maquiavélica - mas pouco sociológica -, seriam apenas os "órfãos de uma nação". O Capítulo 3 traz transcrições de algumas entrevistas, enfocando aspectos variados da história dos Arara, seus personagens principais, seus deslocamentos, suas idiossincrasias. E por fim, o Capítulo 4 descreve, sucintamente, o processo de retomada das terras pelos Arara e comenta os problemas mais recentes.

Uma advertência aos leitores: incoerências e contradições há e muitas, e podem ser facilmente constatadas, pois não me investi a suprimi-las. Tal inconsistência nos dados, quando não devido totalmente a mim, parece resultar do próprio material com o qual trabalhei: a memória social e individual, somos obrigados a reconhecer, percorre na verdade atalhos tortuosos quando não aleatórios. O que se conserva responde a funções complexas que, de fato, não se encaixam à perfeição às demandas presentes, uma vez que, por definição, têm sua origem em um tempo que se foi - e do qual é, simultaneamente, seu portador. Todavia, embora descontínuas, atadas a paixões e sujeitas aos melindres do tempo, por isso mesmo as recordações nos revelam facetas por vezes inesperadas dos acontecimentos passados que interpretam - e a isto devem propriamente seu inigualável poder de sedução.

\section{Capítulo 1 O êxodo: do seringal à cidade}

Uma investigação etnológica sobre os chamados índios Arara, cujo habitat está delimitado pelos rios Branco e Guariba, no Município de Aripuanã (MT), requer, sobretudo, uma leitura cautelosa das fontes históricas, de maneira a interrogar numa perspectiva ampla as relações étnicas aí envolvidas. Pois sob tal etnônimo, ao que tudo indica, vieram abrigar-se diversos grupos indígenas que, a partir do início do século XX, passaram a conviver e a trabalhar nos seringais que se instalaram nos vales do rio Aripuanã e seus afluentes.

A denominação Arara, devo salientar, já era de uso corrente nesta zona do médio Aripuanã e ao longo do Madeira desde a segunda metade do século passado, sendo então empregada para, notadamente, designar índios aguerridos que hostilizavam feitorias e vilas, redutos missionários e aldeias Mura ${ }^{8}$. A alcunha daí

\footnotetext{
8 Ver por exemplo a informação prestada em 1848 pelo Diretor Geral dos Índios da Província de Mato Grosso, Joaquim Aives Ferreira, sobre os Arara de então: "Esta nação é bastante numerosa. Habita em diversas aldeias à margem do Madeira desde o salto do Girão até o Rio Jamary. Mantêm-se da caça e pesca e occupão-se tambem de lavoura e fião algodão. Os Aráras são bravios e vivem em crúa e constante guerra com os Muras e outros vizinhos, nações indigenas, e comem a carne dos seus inimigos. São propensos ao roubo e à matança e procurão todos os meios de fazer mal" (FERREIRA, 1905: 91). Os Relatórios dos presidentes da Província do Amazonas registram vários conflitos envolvendo índios den ominados Arara. Exemplos de embates entre os Arara e os Mura, nas proximidades da foz do Aripuanã, foram examinados por
} 
em diante foi atribuída a vários outros povos encontrados na região ${ }^{9}$, o que poderia ocasionar controvérsias, por vezes insanáveis, para uma identificação unívoca das etnias que aí habitavam. Por esta razão, um inventário histórico, isto é, a consulta abrangente tanto das fontes documentais como da memória que se transmitiu de uma geração à outra (uma vez que os fatos aqui tratados são, por assim dizer, ainda recentes, pois concernem, sem nenhuma exceção, ao presente século), parece ser de alguma valia para a compreensão do estado atual daquela população indígena.

\title{
As primeiras notícias
}

Já em 1914, por ocasião da Expedição Roosevelt-Rondon que explorou o atual rio Roosevelt, afluente do rio Aripuanã que até aquela data os seringueiros conheciam por Castanha ou Castanho, o então coronel Cândido Rondon soube da existência de índios chamados "Araras" que viviam no rio Guariba. Estes, diversamente dos grupos hostis que habitavam o alto Aripuanã, teriam permitido o estabelecimento de civilizados no seu território. Acerca destes Arara, apresentou o coronel Rondon os seguintes comentários durante as Conferências que pronunciou no Rio de Janeiro em 1915:

\begin{abstract}
Ha, porém, abaixo da mencionada cachoeira (Infernão), um affluente, o Guariba, regularmente povoado pela nossa gente, não obstante existirem nelle tambem muitos indios. Segundo informações do Sr. Caripé, que é o maior proprietario do Roosevelt, os selvicolas desse affluente pertencem a uma tribu differente da que hostilisa os seringueiros no rio principal; aquelles são os denominados Araras, e os outros serão, provavelmente, de alguma tribu da grande nação dos Múras. (RONDON, 1916: 108-109)
\end{abstract}

Conforme os relatos que Rondon (1916: 104) recolheu dos moradores do Roosevelt, sabe-se ainda que os seringueiros, ávidos por látex abundante, teriam começado a subir o rio Aripuanã e seus afluentes a partir de 1879. Do que sucedeu nestes trinta e tantos anos, até que viesse a expedição de Rondon, nada ainda se apurou, seja porque se extraviaram os documentos relativos a tais acontecimentos seja porque destes, mais provavelmente, os primeiros "conquistadores" não pretenderam nenhum registro. Certo é que, a exemplo do médio Madeira e outras zonas extrativistas na Amazônia, fatalmente esta frente pioneira não deixaria de desencadear conflitos e violências incalculáveis ${ }^{10}$, pois toda aquela imensa região, como se depreende das notícias que de lá vieram nos anos seguintes, estava ainda densamente povoada por inúmeros e numerosos grupos indígenas ${ }^{11}$.

Pinheiro (1969/72: 53-54). Outras referências mais extensas podem ser encontradas em Menéndez (1981/82).

9 Eduardo Barros Prado (1959: 69-70), num dos livros onde relata suas viagens e aventuras pela região amazônica, conta o caso de uma visita de 160 índios "Araras" ao seringal Vera Cruz no rio Castanho (Roosevelt), de propriedade de Lauro Paéz. Sem mercadorias para atender a tantas pessoas e atemorizados pela conduta dos índios, os quais pegavam o que lhes agradava, o proprietário e seus empregados abandonaram o seringal às escondidas. Nesta mesma obra o autor traz informações e fotos dos igualmente nomeados “Arara” nos rios Canumã e Sucunduri (idem: 98-108).

${ }_{10} \mathrm{O}$ denodado inspetor Bento Pereira de Lemos, que durante muitos anos dirigiu a Inspetoria do SPI no Amazonas e Acre, chamou a atenção da direção do órgão, por diversas vezes, para o estado crônico de violência que imperava na região do Aripuanã. No relatório de 1924, por exemplo, após dar conhecimento do assassinato de Agesiláo Carvalho Guilhon, exencarregado do posto do rio Madeirinha, exatamente quando tentava "arrebatar do poder do assassino Alcino Pereira uma pobre india que estava sendo submettida às mais deshumanas sevicias", o inspetor solicitava o restabelecimento dos postos indígenas Madeirinha, Guariba e alto Aripuanã que haviam sido suspensos por falta de crédito: "A restauração desses postos é mais que necessaria, no momento actual, dada a falta absoluta de policiamento naquellas regiões onde seringueiros e caucheiros, peruanos e brasileiros, costumam agir obstinadamente, não respeitando os direitos dos civilizados tampouco dos selvicolas que são encontrados em zonas inaccessiveis à vigilancia dos Delegados desta Inspectoria" (SPI Inspetoria do Amazonas e Acre, 1925: 21). E acrescenta adiante: "o valle do Aripuanã é um dos perigosos scenarios onde campeia o banditismo" (idem: 22).

${ }^{11}$ Um ofício de Francisco Bayma do Lago, delegado do SPI no rio Roosevelt, datado de 30 de junho de 1919, sublinha a quantidade e a diversidade da população indígena à época: "no rio Castanha existe muitas tribus e das quais umas duas estão domesticadas e conta em numero de oitenta. No rio Aripuanã, aonde é o maior numero, tem approximadamente uns dois mil quasi todos bravos. Assim calcula-se devido ter-se encontrado inummeras malocas. No alto Roosevelt calculase um mil e tantos" (LAGO, 1919). 
E neste ponto uma primeira distinção deve ser feita, a saber, entre os Arara do Guariba, que não hostilizavam os seringueiros, e as outras etnias que viviam nos lados do Aripuanã. Tal assertiva já a havia feito Rondon, por ocasião de sua passagem pela região. O Mapa Etno-Histórico de Curt Nimuendaju (1981), por sua vez, traz a este respeito dados que confirmam a existência de pelo menos duas etnias na área: uma primeira referência, datada de 1918, sobre os "Arara" no alto Guariba; e outra, de 1929, assinalando um grupo sob a denominação genérica de "índios" à margem direita do rio Aripuanã, na altura da divisa dos Estados do Mato Grosso e Amazonas.

As referências no Mapa de Nimuendaju, provavelmente fornecidas por Agesiláo Carvalho Guilhon e Henrique Magnani, servidores do então Serviço de Proteção aos Índios - SPI, nos conduzem às primeiras evidências etnográficas. Veremos adiante quais outros indícios podem ser apresentados, de modo certificar as origens múltiplas desta população que é hoje identificada e se identifica como Arara ${ }^{12}$.

\section{Seringais e seringueiros}

A frente extrativista, que passou a explorar os ricos seringais e castanhais nativos, se espalhou rapidamente e ocupou tanto os rios principais como seus tributários. Estava composta, em sua maior parte, por peruanos, bolivianos, venezuelanos, cearenses e alguns amazonenses - e, pouco tempo depois, também por índios oriundos dos povos que ali viviam.

A firma J. Negreiros \& Cia., uma das maiores empresas envolvidas na produção e na comercialização da borracha por toda a Amazônia, aí estava com um grande número de aviados (ou fregueses) e batelões (barcos) para o transporte fluvial até Manaus. Sua atuação envolveu, direta ou indiretamente, vários grupos indígenas que viviam nos rios Roosevelt e Guariba. Já no rio Aripuanã e suas adjacências, é a ação do peruano Alejandro Lopes que merece maior atenção. Ele se tornou proprietário de todos os seringais compreendidos entre o salto de Dardanellos e a cachoeira de Samaúma, reinando como um senhor absoluto da vida e da morte, de seringueiros e de índios.

Sob as ordens de dom Alejandro, bandos armados dizimaram sistematicamente os grupos indígenas que resistiam à ocupação de seus territórios. Alguns destes fatos chegaram a ser denunciados à Inspetoria do SPI, sediada em Manaus, a exemplo do massacre em 1927 de índios "Iamé" (os atuais Cinta Larga) no alto Aripuanã, a montante da cachoeira de Dardanellos, no qual foram barbaramente mortos dezenas de índios ${ }^{13}$. O inquérito policial, mesmo após oitiva das testemunhas, não teve, todavia, seguimento em razão das injunções que fez Caetano Cabral, "sócio e amigo" do seringalista Lopes. Ele solicitou a intervenção de políticos

\footnotetext{
12 O missionário Manoel Valdez, do Conselho Indigenista Missionário - CIMI, em seu primeiro relatório observava que eram identificados como Arara dois grupos distintos, um seria "originalmente das cabeceiras do rio Guariba", o outro do rio Aripuanã. Deste último, as malocas estariam "antigamente nas proximidades do Salto de Dardanelos", ou seja a atual sede municipal de Aripuanã (VALDEZ, 1984: 2). Também sobre a existência de vários grupos na região, ver as entrevistas no Capítulo 3 desta coletânea.

13 Este é um dos poucos casos onde as informaçoes sobre os autores são mais extensas. O bando que em outubro de 1927 atacou a aldeia dos Iamé nas proximidades do Riozinho, acima da Cachoeira Passa Se Podes, a montante da cachoeira Dardanellos, estava composto por assalariados e fregueses de Alejandro Lopes e foi chefiado pelo peruano Júlio Torres. Da carnificina não foram poupadas nem mulheres nem crianças: "Ha referências sobre essa barbara sangueira que enche de indignação e de horror, entre estas a do espostejamento de criancinhas, que, jogadas para o alto, eram aparadas e trespassadas pelos terçados afiados dos deshumanos matadores, e tambem a morte de uma india em estado interessante, a quem rasgaram O ventre para matar o filho" (SPI, 1929: 181).

Como esclarece o inspetor Bento Lemos, no ofício onde requer a abertura do inquérito policial, o extermínio dos Iamé foi motivado "pelo facto de serem as terras onde os indios tinham suas malocas muito ricas em caucho e recear Alejandro que os selvicolas obstassem a entrada de seu pessoal por aquellas paragens" (idem: 181-182).
} 
junto ao presidente do estado do Amazonas e, ao mesmo tempo, dissuadiu as principais testemunhas através de ameaças, intimidação e suborno. Como constatou o inspetor do SPI Bento Lemos, o poder do "peruano dinheiroso e perverso" se estendia muito além do longínquo Aripuanã (SPI, 1929: 180-183).

Convém observar, contudo, que a vários grupos indígenas parece ter surgido como alternativa, provavelmente, uma escolha estratégica diante do avanço contínuo dos seringueiros sobre seu território, a aproximação amistosa e, de uma ou outra forma, sua própria incorporação à empresa extrativista. Este seria $\mathrm{O}$ caso tanto dos índios "Vela", sobrenome que identifica os atuais Arara do rio Branco, como também de ao menos dois outros grupos no Guariba, um do igarapé Novo e outro do Moacir, os quais buscaram deliberada ou forçosamente o convívio com os seringueiros. Para descrever o processo histórico de sua inserção nos seringais, pois é esta a tarefa que aqui pretendo, além da consulta aos poucos documentos existentes, será necessário interpretá-lo à luz da memória viva dos índios e dos antigos seringueiros.

Uma primeira observação. A vida econômica e social nos seringais teria atravessado dois períodos bastante distintos: uma época áurea, de grande "fartura"; e outra, de derrocada do extrativismo, quando começaram a "arruinar" e a abandonar as colocações mais distantes. Este processo teria se intensificado com a venda das terras ao "comendador" Manuel Pedro de Oliveira em meados da década de 50 (SANTOS, 1987: 11).

Se tal trajetória de decadência em nada parece diferir do próprio ciclo produtivo da borracha na Amazônia (cf. ARNAUD e CORTEZ, 1976: 24), esta não foi a opinião que dela fizeram índios e seringueiros, que antes atribuíram seu empobrecimento às práticas extorsivas impostas pelo novo proprietário do alto Aripuanã. No depoimento aos padres Júlio Hebinck, franciscano americano, eJúlio Vitte, secular francês, por ocasião de uma viagem de desobriga que realizaram em 1971 (subindo o rio desde a cidade de Novo Aripuanã (AM) ao salto de Dardanellos), dois velhos moradores assinalaram que havia no tempo de Alejandro Lopes cerca de "1.000 facas (seringueiros) e 500 machados (derrubadores da árvore caucho)”. Tendo chegado àquela região em 1919, estes moradores acrescentaram:

\footnotetext{
Naquela época vivia-se muito melhor do que hoje. Nada faltava, estiva farta, manteiga, queijo etc... de 1930 para cá dizia o velho Antônio, chamado Paraiba, nunca mais vi a cor do queijo, nem por sonho! (HEBINCK e VITTE, 1971: 2)
}

De Jacaretinga ao salto de Dardanellos, o alto Aripuanã era então referido pelos próprios seringueiros como "rio do cativeiro", pois, devido aos preços exorbitantes que vigoravam no seringal de Manuel Pedro de Oliveira, eles não conseguiam "tirar saldo" e ficavam à mercê do patrão Pedro de Oliveira. Sem assistência médica, sem escolas, sem mantimentos, foi assim que os padres Hebinck e Vitte os encontraram em 1971:

Neste trecho do rio existem 60 casas, das quais 31 abandonadas e 29 habitadas. O sonho dos moradores dessas 29 casas é sair o quanto antes! Até um patrão que dizia ganhar um bom dinheiro, pois tudo falta: mais de ano sem arroz, mêses sem café, sem medicamentos, sem fazenda. "Aqui dizia uma patroa, é a pior coisa do mundo, quando se chega aqui, só falta morrer, aqui não tem uma xícara de café!” Como sair do cativeiro? "Os patrões, dizem os seringueiros, não dão condução nos seus batelões. O jeito é fazer uma canoa, e arriscar a vida nas 22 cachoeiras"? (HEBINCK e VITTE, 1971: 8)

O estado de submissão em que viviam os seringueiros iria, inclusive, surpreender vivamente o então recém-nomeado prefeito de Aripuanã, Sebastião Otoni Sobrinho. Havendo visitado a sede municipal em meados de 1971, em seu primeiro relatório ao governador do Estado, do qual extraí o trecho abaixo, ele se 
detém numa descrição pormenorizada do esquema montado pelo seringalista, situação que intitula de "escravatura feudal":

vez por outra éramos inquiridos com a seguinte pergunta: 'Será Prefeito que o senhor agora irá conseguir derrubar a escravatura branca implantada pelo Manoel Pedro de Oliveira do Amazonas? Então ao chegarmos ao Salto dos Dardanelos e abaixo dêste, era o que mais ouvíamos dos infelicitados escravisados (...).

Trata-se segundo informações, de um todo poderoso seringalista de Manaus, que se diz proprietário até acima do Salto dos Dardanelos, desde o rio Madeira. Os coitados foram trazidos, a maior parte do Nordeste, influenciados via de falsas propagandas de enriquecimento rápido, através da extração do leite da seringueira e outros. Ao soltálos nos seringais, o fornecimento não vai além de um pouco de farinha d'água, sal, algum quilo de açúcar, pólvora e chumbo, algum antimalárico e alguma coisinha a mais e de menor significância.

Quando vem o capataz recolher o fruto da exploração (...) no ato do recebimento já vai descontado 30\% sobre o valor da borracha como arrendamento do seringal, não falando o pêso de suas balanças que são bastante discutíveis. Nêste ponto o miserável com sua família, já se encontram nus e valendo-se de uma qualidade de côco que por lá existe em abundância para alimentação, quando não logra pescar algum peixe, já que mais nada têm para se comer. Aí agora vem a segunda parte do drama: a sua produção vai levada a preços de miséria, enquanto que o reabastecimento de roupas e gêneros, aquele acima numerados o são à preços de ouro. Resultado: da primeira entrega já fica o arrendatário atingido por saldo negativo, só que desta feita ainda comprou alguma coisa em maior quantidade, mas da outra em diante é o que o todo poderoso Manoel Pedro de Oliveira determinar. Daí em diante nunca mais o infelicitado conseguirá saldo. E se algum ousado vier a atingi-lo, aí agora é que...Vale a lei da selva!" (SOBRINHO, 1971: 6)

As descrições acima, ainda que excessivamente impressionistas. Parecem, todavia, suficientes para o que se pretende, a saber, uma contextualização do sistema extrativista ${ }^{14}$ que então vigorava na região do alto Aripuanã, sistema no qual vieram os índios a se inserir. Em quase tudo semelhante a tantos outros exemplos por toda a Amazônia - a não ser, talvez, pela presença proeminente de tantos peruanos, venezuelanos e bolivianos, como aqui se verificou -, à empresa seringalista, caracterizada pelo mecanismo do aviamento e pelas relações de extrema submissão dos chamados fregueses ao patrão do seringal ou ao marreteiro do rio (comerciante), iria moldar social e economicamente a vida regional, marcando de forma indelével as populações a ela submetidas, sejam os migrantes nordestinos ou as comunidades indígenas.

\section{Os Arara do rio Guariba}

Vejamos agora a procedência dos grupos indígenas que foram incorporados a este sistema extrativista. Sob a denominação Arara, como se disse acima, o então coronel Rondon já havia recebido, em 1914, notícias de um grupo indígena no Guariba, que não hostilizava os seringueiros. Ouvindo o relato de antigos moradores deste rio, ainda que não seja possível datar ou descrever com muita precisão os contatos iniciais entre índios e seringueiros, encontrei fortes evidências de ao menos dois grupos indígenas que, nesta área, vieram a gravitar em torno dos barracões dos seringais: um proveniente do igarapé Novo e outro do igarapé Moacir15.

14 Para uma exposição detalhada do modo de vida dos seringueiros e as relações socioeconômicas vigentes nos seringais do Madeira e afluentes, ver Hugo (1959: 161-166). Já o impacto da frente extrativista sobre as populações indígenas na Amazônia foi examinado por Darcy Ribeiro (1982: 21-47).

${ }_{15}$ É certo que havia vários outros grupos indígenas na região do Guariba. Em busca de notícias sobre índios isolados, por exemplo, o aventureiro Eduardo Prado soube da existência de um grupo de "Orelhas-de-Pau" (Rikbaktsa) que vivia nas nascentes deste rio. Ele interrogou, em Manaus, no ano de 1951, a Deodoro Cavalcanti, que durante sua juventude havia trabalhado como mateiro na firma Bayma do Lago \& Cia., estabelecida com seu barracão em Prainha, no rio Aripuanã. 
Provavelmente na segunda década deste século um grande número de índios se aproximou de um seringueiro no rio Novo, afluente da margem direita do Guariba. Cerca de trezentos foram então levados para a colocação Alegria (local da atual ponte na estrada para o Projeto Filinto Müller) e ali utilizados pelo seringalista Pedro Adolfo, cuja área de exploração de borracha se estendia da colocação Soledade (na atual divisa MT/AM) até o igarapé Poção. Segundo o missionário Valdez, haveria duas versões para estes acontecimentos:

\begin{abstract}
Os primeiros contatos no Guariba teriam sido realizados pelo seringalista Pedro Adolfo, através de presentes deixados nas trilhas utilizadas pelos índios. A velha Guilhermina, índia Arara que saiu do Guariba ainda menina pequena, afirmou, no entanto, que teriam sido os próprios índios que procuraram os seringueiros, pois estavam sendo atacados pelos Cinta Larga e Cabeça Seca. Os índios, em grande número, chegaram na casa de um seringueiro, os mais velhos na frente carregando suas flechas com a ponta para baixo. (VALDEZ, 1984: 2)
\end{abstract}

Liderados por Caetano, Tibúrcio e Chico Velho, que são os nomes que então receberam, construíram suas malocas e fizeram seus roçados, espalhados em cerca de dez aldeias entremeadas às colocações dos seringueiros. Caetano se tornaria uma espécie de "patrão" junto aos seus patrícios, adquirindo, inclusive, um batelão para transportar a borracha e trazer de Manaus as mercadorias (VALDEZ, 1984: 2; SANTOS, 1987: 16-17). Saindo da colocação Alegria, estes Arara foram trabalhar no igarapé Moacir com o seringalista Jerônimo Marinho ${ }^{16}$. Com a morte do seringalista, no entanto, teriam sido expulsos pelo novo proprietário do seringal, Antônio Aleixo Moura, quando então alguns se deslocaram para seringais próximos e outros retornaram aos locais das antigas aldeias. Mas o sarampo e a varicela, pelo que se sabe, teriam se encarregado de dizimar a maior parte deste contingente indígena.

Outras versões assinalam o igarapé Moacir como habitat original deste grupo. Numa interessante pesquisa a cabo do Sindicato de Trabalhadores Rurais de Aripuanã, ao tratar especificamente da ocupação indígena da região, foram registradas passagens da história do patrão indígena Caetano, que abaixo transcrevo:

\begin{abstract}
Aproximadamente a 65 anos, no alto do Rio Guariba, localizada em suas margens, havia uma tribo de índios conhecida por Araras. Na época houve muitos atritos entre índios e seringueiros que entraram para extrair borracha nos seringais da região, houve casos de índios matar seringueiros e seringueiros matar índios. Na época a situação era de vida ou morte.

Aconteceu então que uma família de índio Arara tinha um menino que na tribo recebia o nome primitivo de Gavião e este menino encontrou-se com um senhor conhecido por Manuel Macário e passou a viver com os seringueiros. Os encontros entre Manoel Macário e o menino Gavião se deram no Igarapé Moacir, um afluente do rio Guariba. Manoel Macário tinha vocação para civilizar índios, e este menino, Gavião, foi mais tardebatizado, e levou o nome de Manoel Caetano. Com isto o menino Manoel foi motivo de aproximação de toda a tribo, que passou a viver em paz com os seringueiros.

Casou-se e com sua gente colhia borracha... Ainda hoje existem descendentes de Mangel Caetano na região, Conforme contam os índios e seringueiros, o primeiro encontro pacífico em grande escala entre índios e os seringueiros, se deu no ano de 1938, quando um grande número de índios Araras saiu em um campo onde havia uma sede de seringueiros. Pegos de surpresa, os seringueiros lançaram as mãos nas armas. Os índios, no
\end{abstract}

Cavalcanti fora enviado para tocar um seringal chamado "Payurá” [Pajurá], no rio Guariba, que depois veio a pertencer à firma J. Negreiros \& Cia. Este seringal encontrava-se acima do salto Ribeirão, a partir do qual Cavalcanti distribuía a mercadoria entre os aviados: “ e com o mesmo fim se dirigia a um seringal de nome Muasí [Moacir]. Este se acha nas nascentes do rio Guariba, onde estão estabelecidos os “orelhas de pau”, orelhões ou, mais comumente, chamados coborós. Estes orelhas de pau se caracterizam e tomaram seu nome, por levar pendentes das orelhas uns adminículos de madeira em forma cônica que atravessa-lhes o lóbulo. Com o tempo e por obra de seu peso, chegam em adultos até quase tocar os ombros". Deodoro mostrou-lhe exemplares destes adornos, comentando que os seringueiros peruanos que desbravaram a região (os subordinados de Alejandro Lopes) colecionavam-nos junto com a orelha do índio morto a tiros, como troféus (PRADO, 1959: 64-67).

16 Ver a entrevista no Capítulo 3 com o ex-seringueiro Raimundo Santos, que conheceu tanto os Arara no Guariba como no rio Branco. 
entanto, jogaram as armas no chão, e os seringueiros, vendo isso, largaram também as armas, e houve a aproximação entre eles, e Manoel Caetano acompanhado do tuchaua (chefe) Maran Kati, achavam-se na frente da tribo.

E Manoel Caetano, falando um português meio atrapalhado servia de intérprete. Os índios gesticulavam e pronunciavam muitas vezes a palavra papai. O chefe Maran Kati vendo uma situação pacífica entre índios e seringueiros distribuiu o seu povo em diversas malocas nas margens do rio Guariba, entre os seringais. E Manoel Caetano continuou servindo de intermediário entre índios e brancos. Mais tarde tornou-se o tuchaua da tribo. Manoel Caetano, o Gavião, morreu de morte natural. No decorrer da vida teve duas mulheres e muitos filhos.

O seu povo, no entanto, foi mais tarde acometido de um surto de gripe. Em uma época e local sem recursos medicinais, a tribo foi quase dizimada. Os sobreviventes estão dispersos na região. (MALTHEZO, 1990a)

Em fins da década de 40 um segundo grupo indígena teria se aproximado dos seringais no Guariba. Desta vez mais de cem índios saíram no barracão do patrão Jerônimo Lopes Marinho, localizado no referido igarapé Moacir, à margem direita do Guariba ${ }^{17}$. De acordo com as informações etnográficas e linguísticas disponíveis ${ }^{18}$, eles seriam componentes de um dos grupos Tupi-Mondé que estariam buscando refúgio devido a conflitos com grupos inimigos, mas que foram chamados Arara como os anteriores. Vestidos "tudo de vermelho" e batizados pelo patrão Jerônimo, logo começaram a trabalhar na seringa. Porém pouco tempo depois, teriam contraído uma forte epidemia de gripe, uma "gripe doida", segundo a expressão da informante dona Mocinha, da qual muitos vieram a falecer.

Na pesquisa realizada pelo Sindicato, acima aludida, surgiram outras informações preciosas a respeito deste grupo do igarapé Moacir, que complementam o relato que me fez dona Mocinha:

Seringalista que vivia no vale do Igarapé Moacir, [Jerônimo Marinho] dirigiu turmas de seringueiros, aproximadamente entre os anos de 1945 a 1954. Possuía uma sede organizada, onde havia plantação de mandioca, cana e milho, além de árvores frutíferas, havia também na sede gado, mulas, galinhas e porcos. Na dita época, os índios Arara já bastante civilizados, moravam em grande número em casebres, ao redor da sede de Jerônimo Marinho, e trabalhavam na extração de borracha (...) a troco de comida, roupa, armas, munição, calçados e despesas de viagem para Manaus. Esta ajuda aos índios Arara fez com que Jerônimo Marinho e seus companheiros ficassem muito ricos.

Uma observação (...) é que o Igarapé Moacir, afluente do Rio Guariba, foi terra natal dos índios Arara. Lá existem Campos Santos [cemitérios], onde estão enterrados muitos Arara e que os atuais sobreviventes lembram com muito respeito. (MALTHEZO, 1990b)

O missionário Vítor Hugo (1959: 266), que, por sua vez, subiu o rio Guariba em 1958, informa tão-somente que encontrou "um grupo de índios mansos nas cabeceiras", dos quais o padre Bento de Sousa, pároco de Borba, haveria colecionado uma lista de vocábulos.

\section{Os Arara do rio Branco}

Acerca destes índios os dados se mostram mais abundantes e precisos. O servidor do SPI Agesiláo Carvalho Guilhon, que chefiava o posto do rio Madeirinha, notificaria em, 1919, um ataque aos seringueiros no rio Branco, confluente do Aripuanã, assinalando a existência ali de grupos indígenas nos seguintes termos:

houve ainda ataque dos indios Nhambyquara, ou Suruy - como são coghominados por seus parceiros já domesticados - não tendo, porem, havido victimas a lamentar. Convem salientar que os ataques levados a effeito por esses indios, não têm outro intuito

${ }_{17}$ Ver no Capítulo 3 a entrevista com dona Mocinha, ex-moradora do Guariba que os viu quando chegaram no barracão daquele seringalista.

${ }_{18}$ Ver Vocabulário Arara do Guariba, no Apêndice 1 desta coletânea. 
senão o de apoderarem-se das ferramentas de trabalho - de que elles fazem grande cabedal - e que não conseguem obter por outros meios. (GUILHON, 1919: 1)

Estes seringueiros, muito provavelmente, eram aviados de um dos dois barracões que o seringalista Lopes havia mandado instalar no rio Branco - um nas proximidades do igarapé Veadinho, sob a gerência de Olegário Vela, e o outro na cachoeira Palmeirinha, administrado por "dom" Geraldo (SANTOS, 1987: 8). Os índios passaram a acompanhar os movimentos dos seringueiros, não se importando em deixar sinais de suas andanças ao redor das colocações - e mesmo, como noticiado acima, chegando a saqueá-las algumas vezes.

Por outro lado, reinava um estado de guerra com os demais grupos indígenas da região, em particular os Cinta Larga, os Zoró e os Rikbaktsa, e isto reforçou a disposição dos Arara para tentar um relacionamento amistoso com os civilizados19. Assim que, em 1923, ocorreu a Olegário Vela convencer uma turma de índios a trabalhar para ele. Integrados à vida do seringal, estes índios vieram a adotar o sobrenome do "pacificador", depois transmitido a seus descendentes. O historiador Vítor Hugo, missionário salesiano da Prelazia de Porto Velho que os encontrou em 1958 ainda vivendo na localidade de Três Tombos, no rio Branco, recolheu o seguinte relato deste episódio:

\begin{abstract}
Naquele ano, certo Olegário Vela encontrava-se extraindo caucho no Alto Rio Branco, afluente da margem esquerda do Rio Aripuanã, quando foi prêso numa cilada, por certa maloca de índios. Percebendo, entretanto, as intenções pacíficas dos raptores, deixou-se conduzir até a maloca. Permaneceu no meio dêles coisa de um mês, até convencê-los a acompanhá-lo à colocação para trabalharem na extração do caucho e, posteriormente, da borracha. (HUGO, 1959: 264)
\end{abstract}

Outras versões para estes fatos são também conhecidas ${ }^{20}$. Um ex-seringueiro do rio Guariba, apelidado Pará, que, em 1992, quando o conheci, trabalhava na balsa do rio Aripuanã, contou que há cerca de cinquenta anos atrás um cearense teria ido à maloca dos Arara e, no prazo de quatro "luas" (meses), de lá vieram mais de uma centena de índios para o Salto de Dardanellos (atual Aripuanã). Haveria então, segundo ele, três agrupamentos no rio Branco: na cachoeira Pavorosa, na Palmeirinha (pouco acima de Três Tombos) e no Capivara (ou Veados).

Os atuais Arara, no entanto, confirmam em linhas gerais o relato que foi obtido por Vítor Hugo em fins da década de 50. Dizem que antes havia uma única e grande aldeia na cachoeira Pavorosa, da qual Miguel (pai de Rodrigo Vela) seria o cacique e Adeca o tuxaua. Lé, segundo eles, "era só matando gente; não tinham patrão nem trabalhavam na seringa”. Numa tática aparentemente para seduzilos, o gerente Geraldo deixava-lhes na foz do igarapé Encrenca algumas "mercadorias" (brindes), que apanhavam e levavam para sua aldeia. Numa ocasião, os índios encontraram Olegário (irmão de Geraldo, segundo os informantes Arara) neste local e o levaram para a Pavorosa ("ele tremia de medo", sublinharam). Olegário Vela teria daí descido com os índios até seu armazém, na foz do rio Branco. O grupo de Miguel veio depois a se instalar em Três Tombos, onde começaram a trabalhar na seringa aviados pelo patrão Geraldo. Ali, porém, eram ainda assediados pelos Cinta Larga, e alguns foram viver no Capivara, outros no Veados.

\footnotetext{
19 Vimos acima que, da mesma maneira, ataques de grupos inimigos teriam forçado o deslocamento dos Arara do Guariba. ${ }^{20}$ O velho Chico Jerônimo, ex-soldado da borracha e antigo morador da vila de Aripuanã, contou-me, em 1982, uma versão ligeiramente diferente. Acossados por outros caboclos (índios) que todos os anos apareciam para pilhar suas roças e matalos, os Arara planejaram colocar-se sob a proteção dos seringueiros que há anos estavam estabelecidos nas barrancas do rio Branco. Receavam, porém, além das armas de fogo, que seu gesto não fosse bem compreendido. Os motores então já subiam o rio, e os Arara espreitavam seguidamente os seringueiros. Um dia, capturaram um tal Chico Pretinho que lavava roupa na canoa, distraído, longe do seu rifle e convidaram-no a segui-los até a maloca. Passados alguns dias, Chico Pretinho quis regressar e os índios acompanharam-no até o barracão. Consumado o "amansamento", os Arara ali levantaram seus tapiris. O seringal comemorou, festivamente.
} 
O peruano Olegário Vela, que apadrinhara estes índios e era por eles chamado de "Delegado" - lembram-no hoje como "a nossa FUNAI antiga", ou seja, como se fosse um servidor do SPI -, morreu de febre possivelmente em fins da década de 30. Fragmentos destes tempos foram rememorados por dona Abigail, filha de venezuelano que à época dos contatos morava no rio Branco (tinha então uns 15 anos de idade). No relato que fez à antropóloga Vera Lopes dos Santos:

[Ela] Conhecera as últimas famílias de índios Arara que ainda permaneciam nas suas malocas originais (duas malocas). Estas malocas localizavam-se próximas ao igarapé Poraqué (margem esquerda do Aripuanã). Refere-se a estes índios como *mansos' e "pacíficos". Ao contrário da afirmação de Vítor Hugo [ver abaixo], esta senhora nos relatou que os índios Arara usavam de fato, penas de arara nas orelhas e no lábio inferior (daí a denominação do grupo pelos brancos) ${ }^{21}$, além de uma tanga feita de algodão. Somavam aproximadamente 10 famílias, que inicialmente vieram para a beira do rio Branco, fixando-se ao lado do barracão de Olegário Vela. (SANTOS, 1987: 10)

A viúva de Olegário Vela, a peruana Ema, se casou então com dom Geraldo, o gerente do Palmeirinha, e juntos passaram a administrar os barracões do rio Branco. Pouco depois, por motivo não esclarecido pelas fontes ou informantes, se suicidaria o despótico Alejandro Lopes, enforcado em Manaus. A viúva dona Valentina, por sua vez, casou com dom Raul del Aguila, então gerente em Samaúma, no rio Aripuanã (idem, ibidem). Neste momento, parte dos índios do rio Branco já emigrara para as margens do Aripuanã e alguns para o Guariba. É a situação que o subajudante da Inspetoria do SPI Anastácio Cavalcante deparou em 1941, quando da expedição que fez à bacia do Aripuanã para verificar os ataques de índios $^{22}$ aos seringueiros da firma J. Negreiros nas proximidades de Campo Grande e do rio Mureru. O subajudante em seu relatório designa aqueles como "tribu dos Necadês":

A tribu dos Nêcadês, que, ha tempos, foi disimada pela Gripe, quasi na sua totalidade, hoje encontra-se dividida em dois grupos: um desses habita o Aripuanã e outro o Rio Guariba. O grupo residente no Aripuanã consta de 26 pessõas, 9 homens, 11 mulheres e 6 crianças. Os Nêcadês estão pacificados e vivem em promiscuidade com os civilisados. Ao grupo de Aripuanã Don Raul del Aguila dá toda assistencia. Tive oportunidade de vêr e falar, em Vila Samahuma, com três selvicolas, tipos fortes, de estatura regular, morenos, e expressando-se regularmente em português.

Os demais, do grupo, estão no lugar Bom Sucesso, horas acima dos limites do Amazonas, propriedade de Don Raul del Aguila” (apud SPI - Inspetoria do Amazonas e Acre, 1942: 5-6)

Em meados da década de 50 dom Raul faleceu e Valentina, viúva pela segunda vez, partiu para Manaus levando consigo três famílias Arara (é esta uma das razões para que existam hoje vários descendentes Arara residindo naquela capital).

Quando o missionário Vítor Hugo realizou, em 1958, sua viagem de desobriga, verificou uma população indígena de 45 pessoas vivendo na localidade de Três Tombos, no rio Branco, todas com o mesmo sobrenome Vela. Entusiasmado com o "grau de aproveitamento de nossa civilização" que estes índios haviam alcançado, o missionário louvaria em seus comentários as "vantagens do contacto inevitável": os valores morais, os bens materiais adquiridos por meio do trabalho remunerado (na borracha, castanha e farinha) e, acima de tudo, a catequese reli-

\footnotetext{
${ }^{21}$ Por sua vez, um informante (Deca Arara, filho de Ezídio Vela) disse-me que os Arara usavam três penas de arara vermelha, ornamentando a cabeça (informações pessoais).

${ }^{22} \mathrm{O}$ aventureiro Eduardo Prado, no início da década de 50, faz o seguinte comentário acerca dos conflitos entre índios e seringueiros na região: "No Aripuanã, um pouco mais acima de Samaúma, a viúva de Alejandro Lopes, proprietária de "Rio Branco" e "Campo Grande", os dois melhores seringais da zona por seu rendimento, mantém inativas suas propriedades por temor ao índio. A população, receosa do periódico ataque, abandonou o lugar” (PRADO, 1959: 67).
} 
giosa, tais seriam os benefícios proporcionados aos índios pelos moradores daqueles altos rios (pois, explica-nos o historiador-missionário, até então nenhum sacerdote houvera subido o rio Branco). Em seu diário, Vítor Hugo anotou então:

\begin{abstract}
Encontrei todos aquêles índios batizados em casa. Como se diz por aqui, com água, sal, vela. Pai-Nosso, Ave-Maria e Creio em Deus Pai. Rebatizei-os na forma litúrgica da Igreja, para tirar toda dúvida, e foram êles a pedir-me que abençoasse o casamento natural em que estavam vivendo.

É inequívoco o interêsse que algumas famílias de civilizados tomam por aquêles índios mansos. Os padrinhos que êles tomaram no Batismo e na Crisma, não foram meras formalidades. Manoel Francisco da Silva, velho paraense, é casado com uma das mais velhas índias ${ }^{23}$. Chamam-no Manuel Rapadura (...) É o verdadeiro tucháua de tôda aquela gente. Sabe de cor o lugar de nascimento, a idade (dia, mês e ano) de quase todos. É o pai espiritual, o conselheiro, o amigo, o catequista de todos. É respeitado e venerado. Seus conselhos são leis e ordens, poucos lhe desobedecem. (HUGO, 1959: 265)
\end{abstract}

Por ocasião desta visita aos Arara, além de batizar uns seis a oito índios, o salesiano $^{24}$ trouxe dois deles para Porto Velho (RO). José Firmino, então com 13 anos (que se engajou posteriormente no Exército) e seu irmão. Acerca do período anterior à sua integração no seringal, segundo Vítor Hugo, os índios quase nada recordavam, ou talvez preferissem omitir tais lembranças "fechando-se num mutismo exagerado para toda espécie de civilizado". A despeito desta atitude, o missionário extrairia ainda algumas informações relevantes:

Cam(u)ãi, parece mais um nome próprio ou coletivo feminino, não tribal. Hoje todos adotaram o sobrenome VELA. Outrora usavam furos nas orelhas e no lábio inferior: os mais velhos, no entanto, garantiram que nunca usaram nem brincos auriculares, nem outros enfeites no lábio. Dos seus antigos adornos conhece-se ainda a pretina, um cinturão feito de tecido silvestre. Não usavam tatuagem, e sim apenas se pintavam de urucum. (HUGO, 1959: 266)

É controversa, com efeito, a questão da denominação destes índios. Para o subajudante do SPI Anastácio Cavalcante, seriam a "tribu dos Necadês". Já o historiador salesiano, como se vê acima, descarta o coletivo "Cam(u)ãi" e prefere designá-los apenas por "índios Vela”. Enquanto informantes atuais, por sua vez, afirmam que Yugapkatã é sua verdadeira autodenominação (cf. VALDEZ, 1985: 3). Por que, então, nomeá-los Arara, como são hoje conhecidos? Minha hipótese, diante disto, é que esta designação, muito frequente no século anterior e que havia sido, como notou Rondon, atribuída pelos primeiros seringueiros aos habitantes do Guariba, acabou por se estender, de uma maneira ou outra, também aos demais grupos da região, inclusive àquele que ocupava o rio Branco. Entrelaçando seus descendentes por meio de migrações e de matrimônios, os do Guariba e os do rio Branco confundir-se-iam de fato numa única unidade social, e seria, portanto, inevitável que se lhes atribuísse uma identidade étnica comum. Mesmo porque o termo Arara não tem sido historicamente, nesta região, mais que um apelativo para quaisquer índios, uma espécie de sinônimo de uma categoria por si genérica. Identidade, portanto, não específica, de uso francamente polivalente e que serviu à ocasião aos Arara.

Esta população indígena já havia sido atingida por uma epidemia de varicela (ou gripe, como registrou o subajudante do SPI) no início da década anterior; uma segunda epidemia, em 1959, vitimou um grande número de pessoas que moravam no rio Branco, obrigando os sobreviventes a sair em busca de auxílio. Vejamos os depoimentos de Ezídio e de Anita Arara aos agentes do CIMI acerca destes

${ }_{23}$ A esposa de Manuel Rapadura chamava-se Guilhermina (ver adiante um comentário sobre sua biografia).

24 Informação pessoal, na entrevista que mantivemos, eu e Inês Hargreaves, com o ex-salesiano Vítor Hugo em 1984, em Porto Velho, quando este respondia pela Secretaria de Esporte e Turismo do Estado de Rondônia. 
fatos:

Ezídio: Lembro bem quando chegou um branco na aldeia com o corpo cheio de sinais de feridas secas de varicela e que não demorou o povo foi adoecendo e morrendo muitos. Quem pegou primeiro foi Manoel meu irmão e morreu. (...)

Anita: Durante a doença Alexandre (?) foi mandando o povo para Samaúma, Amazonas. Rodrigo e eu acompanhamos os doentes. Meu pai morreu na viagem, na colocação Tapinima à beira do rio Aripuanã. Foi enterrado no local. Mamãe também estava mal, morreu em Samaúma. Morreram também nossos filhos: Luzia de seis anos, Elizabete de oito anos, Lúcia de treze anos, Lucinéia de três anos e Jair de cinco anos. Dentro de três semanas, morreram estes todos e duas semanas depois morreu Alexandre de um ano e seis meses. João, meu filho mais velho, ficou doente primeiro, mas melhorou. E ele que buscava água prá nós. Manoel, Rodrigo e eu também pegamos a varicela. Na viagem de volta chegando no rio Branco, vieram dizer ao Rodrigo: "Teu pai morreu". Nossa maloca grande ficou vazia. Tudo silêncio. Tudo escuro. Acendia a lamparina. Não gosto nem de falar disto. Que tristeza! (...) [Nesta maloca] Morava o Deca e a Vicença e a filha Maria, o cacique Miguel e Raimunda, Orá e Isabel e Raul, meu primo. Todos morreram. (CIMI, 1991)

Posteriormente o filho de Valentina. Raul, venderia os seringais ao "comendador" Pedro Correa. Deteriorando-se as condições de vida dos seringueiros, algumas poucas famílias Arara, entretanto, ainda permaneceriam no rio Branco, porém comercializando sua produção com marreteiros ambulantes (SANTOS, 1987: 10-11). Os demais já haviam abandonado os lugares antigos, saindo em busca de trabalho no beiradão do rio Aripuanã ou no salto de Dardanellos:

Anita: Por causa da doença [saíram do rio Branco] e não tinha mais condição. Rodrigo ficou trabalhando com Anastácio que tocava a seringa. Outros também trabalhavam com ele. $\mathrm{O}$ batelão ficava só no rio Aripuanã. $\mathrm{E}$ quando nós pensou em voltar. tinha esse Marinho Brandão. (CIMI, 1991)

\section{Os silêncios da história}

Reconstruir a trajetória dos sobreviventes, porque tal era a condição dos índios do rio Branco e do Guariba após tais epidemias e o engajamento quase compulsório nas estafantes atividades extrativistas, talvez não seja, devo reconhecer, de todo possível. Haverá lacunas na memória, certos fragmentos que se perdem nos muitos percursos individuais. Estaria este passado condenado à extinção? Seria esta uma tarefa inócua, reunir uns tantos dados incompletos e outros que se contradizem, vasculhar documentos escritos que pouco trazem além de detalhes esparsos? Mas que não se diga estarmos diante da contingência dos fatos, de um discurso disperso ou sem foco. Nesta história sobram evidências, bem como recordações sufocadas e falas propositadamente obliteradas. Pois também estas táticas de esquecimento, entre as tantas outras formas de violência, sempre dizem algo - mesmo que não se saiba o quê, mesmo que na sua opacidade não reste mais que um simples indício da própria violência.

Dos índios do igarapé Moacir, alguns remanescentes - Maria Xapuri e seus filhos - mantêm um firme silêncio a respeito de qualquer fato relacionado às suas origens indígenas, a despeito das muitas evidências. Recusando assim a identidade étnica ${ }^{25}$, quiçá para evitar os preconceitos mais corriqueiros, tal atitude evasiva, porém, não é capaz de livrá-los dos desmandos e da violência generalizada que atingem os despossuídos em geral:

A índia Arara do Guariba, mais velha, Maria Chapuri, recusou-se a falar do passado, e inclusive não assume claramente sua antecedência. O pai de Maria Chapuri fora morto pelos índios Cinta Larga e, após as peregrinações de sua família pelos rios Guariba e

${ }_{25}$ Para um funcionário, a FUNAI que teria insistido em caracterizá-la como indígena, disseram-me que Maria Xapuri respondeu contrafeita: "Índio é quem está no mato!" 


\begin{abstract}
Aripuanã, hoje vive na cidade de Aripuanã, em condições precárias. Todos os seus parentes afirmam que ela ainda fala a língua e tem a memória mais viva de seu povo. Seu filho Eduardo foi expulso, ano retrasado, juntamente com mais cinco famílias de seringueiros, da colocação que ocupava na boca do rio Canumã, afluente da margem direita do Aripuanã, negando-se a falar sobre qualquer assunto que diga respeito ao fato. (SANTOS, 1987: 16)
\end{abstract}

Outros descendentes foram entrelaçando suas vidas com indivíduos de outros grupos indígenas, tanto os do rio Guariba como os do rio Branco, ou com seringueiros das mais diversas procedências. Quando conheci a velha Nazaré Arara em 1987, então com cerca de setenta anos, estava há muitos anos casada com um seringueiro nascido no seringal Pajurá (do Guariba) e residia em Aripuanã há quase quinze anos. Nazaré, no entanto, filha de Francisca Arara e um cearense, era viúva de Raimundo, um dos filhos do chefe Castano. Embora ela tivesse vivas lembranças de sua infância no seringal, seu depoimento demonstra o processo de sobreposição dos grupos indígenas a que me referia acima ${ }^{26}$. E Ezilda, de trinta e oito anos, que a antropóloga Vera Lopes dos Santos (1987: 40) encontrou vivendo em Aripuanã, casada com um filho de Nazaré e Virgílio, é neta de Pedro Corobó, um daqueles Arara que estiveram à frente do grupo que procurou os seringueiros no Guariba.

Um outro exemplo consta do relatório dos padres Hebinck e Vitte que em 1971 subiram o rio Aripuanã. Eles encontraram na cachoeira dos Veados o velho Antônio Felipe de Souza, apelidado Paraíba, casado com uma índia do Guariba. Vivendo na região desde 1919, foi um dos principais informantes sobre a história e as condições dos habitantes deste rio:

\footnotetext{
O Senhor Antônio, chamado o Paraíba, casou com uma índia legítima, da tribo dos Araras, no rio Guariba em 1935. Ela se chamava Ana, foi uma boa esposa, corajosa e trabalhadeira; Ana lhe deu 9 filhos, dos quais apenas dois sobreviveram. (HEBINCK \& VITTE, 1971: 12)
}

E por fim a velha Guilhermina Arara, viúva daquele Manuel Rapadura que o missionário Vítor Hugo conhecera em Três Tombos no rio Branco, vivendo entre os índios Vela - tantos anos que, segundo estes, teria aprendido "seus costumes" (VALDEZ, 1985). Guilhermina, porém, era nascida no rio Guariba, donde saiu ainda criança pequena para viver com o outro grupo. E, curiosamente, foram ela e seu filho Zé Rapadura os que mais resistiram no rio Branco, apenas abandonando sua colocação em 1986, quando a polícia e os jagunços queimaram sua casa e os expulsaram.

\title{
No beiradão e nas cidades
}

Nas décadas de 60 e 70 as condições de vida no alto Guariba e no rio Branco pioraram muito. Muitos índios buscaram o beiradão do rio Aripuanã, outros se deslocaram em direção às cidades: Matá-matá, Humaitá, Aripuanã, Ariquemes, Manaus, Cuiabá... Fora de suas terras tradicionais, iriam enfrentar, nos anos seguintes, toda sorte de pressões. O cenário regional estava passando por transformações abruptas: o governo do Estado estimulava a ação de agropecuárias e colonizadoras e, de maneira acelerada e inconsequente, promovia a venda de grandes glebas de terras consideradas "devolutas".

O sistema extrativista, com efeito, já não convinha aos novos interesses econômicos atraídos para a região. Os seringueiros e os índios, em razão disto, seriam daí desalojados de suas antigas colocações. No ano de 1986 o missionário 
Manoel Valdez, do CIMI, ao descer o rio Aripuanã, encontrou-os desnorteados, temerosos diante dos novos "patrões" que se assenhorearam brutalmente das terras do Aripuanã:

O principal líder e representante do grupo, conhecido como "Carioca", morreu no início do ano em Vilhena (...). Sua esposa ainda na área ocupada pela Colniza, está desesperada. São nove filhos e nenhum em condições de trabalhar.

Outro líder, o Sr. Osório, que perdera um filho no garimpo recentemente acabava de perder outro (...). O acidente foi num caminhão da colonizadora Colniza. Um tanto desnorteado e querendo abandonar o local o mais rápido possível, assinara um documento para a firma cedendo a área que morava e seringal por $\mathrm{Cz} \$ 50.000,00$. Porém os sete anos de trabalho ainda não foram pagos apesar das promessas (...).

Junto com Sr. Osório saíram as famílias de seus filhos e genros (...). Todos seringueiros com colocações (...) que ficam dentro da área de posse atualmente da colonizadora Colniza. Deixaram todos os seus pertences e benfeitorias no local, e sem a presença do Sr. Osório estão com medo de retornar.

Contribuiu para esses temores, o modo violento com que foram despejadas algumas famílias no final do ano passado. Através da polícia de Aripuanã e de Joaquim (capanga de Marinho Brandão e outros grupos), foram queimadas cinco casas de seringueiros e índios Arara forçando-os a saírem do local com as mãos totalmente vazias. Estes estão agora espalhados nos garimpos e outros lugares, sem condições de retornarem a suas colocações e roçados.

Os que ficaram estão em situação difícil e com muito medo pois continuam sofrendo fortes pressões. João Damásio mora sozinho com a mãe e apesar de ter ficado a ermo está disposto a resistir. Alonso Garrido e toda a sua família estão doentes, e Euclides que teve seu barraco queimado, está pela cidade com a esposa enferma por causa de uma fratura. Ademar, Origó, Ocimir, Maranhão, Ocimar e outros passam também por sérios problemas e pressão.

(...) A colonizadora Colniza com seus milhares de hectares está com uma cidade praticamente pronta e a estrada construída recentemente [Aripuanã-Colniza-Bonsucesso], só trouxe até o momento prejuízos e doenças aos seringueiros (os únicos beneficiados continuam sendo os de fora). (VALDEZ, 1986: 2-3)

Desta maneira, índios e seringueiros, mais uma vez, são lançados a um destino comum: uns e outros despojados, empurrados de lá para cá, mão-de-obra para as derrubadas das fazendas, tentando a vida nos garimpos, a caminho da miséria na periferia das cidades. Tal é o quadro vivido pelos Arara:

Alguns vivem em condições muito difíceis, se locomovendo de um lugar para outro sem parar, à procura de um lugar que lhes dê mínimas condições de se fixar. Eduardo que teve seu barraco queimado está no garimpo novamente. Zé Rapadura (filho de d. Guilhermina, que foi forçada a sair de sua terra por Marinho Brandão) está também no garimpo, depois de ter trabalhado com carteira assinada durante onze anos para o mesmo latifundiário. Porém, não recebeu absolutamente nada ao sair. (VALDEZ, 1986: 4).

\section{Capítulo 2 Uma etnia insolúvel 27}

Remanescentes de grupos indígenas que habitavam o rio Aripuanã e seus afluentes Branco e Guariba, os índios Arara padeceram com a burocracia e a omissão governamental. Afastados de suas terras pela violência de grileiros e de capatazes de madeireiras, as famílias Arara haviam se espalhado pelo beiradão dos rios Aripuanã e Guariba e pelas cidades de Aripuanã (MT), Matá-matá (AM),

${ }_{27}$ Este artigo, aqui com ligeiras alterações e correções, foi publicado originalmente sob o título "Nova sociologia da FUNAI impede reassentamento Arara", em CEDI, 1991: Povos indígenas no Brasil 1987/88/89/90 (Aconteceu Especial 18), pp. 442- 445 . 
Ariquemes (RO) e outras, empregando-se na extração de seringa, na pesca artesanal e na fabricação de farinha, ou vivendo de biscates variados (faxina, capina, vigilância).

A partir de meados da década de 80, missionários católicos fizeram levantamentos e encaminharam as primeiras propostas para o reconhecimento da área indígena. Alguns representantes indígenas viajaram para Cuiabá e para Brasília. E vários Grupos de Trabalho vistoriaram a área presumidamente indígena. A FUNAI no entanto, incapaz de reaver as terras dos Arara" ${ }^{28}$, cogitava, talvez por isto, declarar a extinção oficial do grupo. Mediante a formulação de uma inusitada categoria sociológica - "indios dessituacionados" - um assessor da Superintendência do órgão em Cuiabá argumentava em seu laudo que os Arara não teriam direito a uma "área imemorial”, já que estavam irremediavelmente miscigenados e dispersos. Uma Nova Sociologia ou o velho racismo?

A lógica dos vencedores

A década de 60 foi trágica para os grupos indígenas da bacia do Aripuanã, acossados por seringalistas, grileiros e garimpeiros que invadiram seus territórios e promoveram inúmeros massacres. Na década seguinte, contudo, foi o crime oficial que prevaleceu. A Comissão Parlamentar de Inquérito da Câmara dos Deputados que, em 1979, investigou a situação fundiária brasileira, registraria assim, em seus anais, que Mato Grosso estava sendo "palco da maior invasão de terras indígenas do País, na sua maioria griladas e vendidas a grupos”.

No Município de Aripuanã, notadamente, a Companhia de Desenvolvimento do Estado de Mato Grosso - CODEMAT - alienou irregularmente, em 1973, uma área de dois milhões de hectares, adquirida por apenas quatro empresas. Segundo o relatório da chamada CPI da Terra, teria sido o "maior escândalo imobiliário de Mato Grosso". Concomitante às vendas, o Governo Estadual vinha tomando medidas para facilitar a ocupação da região, construindo para isto estradas, instalando a sede municipal e favorecendo a apropriação das terras remanescentes.

Foi daí que os seringais do "comendador" Pedro Correa, assentados em títulos originários do Estado do Amazonas (mas ocupados pelos índios Arara e por outros seringueiros), foram vendidos ao empresário paulista Mário ("Marinho") Brandão. O empresário, em seguida, tratou de tomar e validar junto ao Instituto de Terras do Estado de Mato Grosso - INTERMAT - as posses que existiam nos interstícios das áreas tituladas, açambarcando desta maneira um latifúndio de mais de um milhão de hectares, praticamente todas as terras entre o Guariba e o Aripuanã ao norte do paralelo 10.

E em 1980, por fim, completava-se a retirada forçada dos Arara do Rio Branco. quando a família de José Rodrigo e Anita Vela foi expulsa pelo grileiro Henrique Faveiro ${ }^{29}$, para quem estavam ultimamente trabalhando na extração de seringa, pouco ao sul do paralelo 10. O "patrão" tomou-lhes todos os pertences, inclusive a borracha acumulada, e eles desceram a remo o rio Branco. Vieram fixar-se na vila de Aripuanã, onde foram abrigados por Durval França, então diretor da Escola dos Seringueiros. Doentes e desnutridos, viveram por vários meses de auxílios e doações dos moradores da cidade.

No segundo semestre de 1984, uma equipe coordenada pelo padre Manoel Valdez, do Conselho Indigenista Missionário - CIMI, realizou um levantamento

\footnotetext{
${ }^{28}$ Referida inicialmente como Área Indígena Arara do Beiradão, recebeu posteriormente, por exigência dos próprios índios, a denominação de Área Indígena Arara do Rio Branco.

${ }^{29}$ Henrique Faveiro acabou sendo assassinado anos depois, ao que tudo indica em razão de conflitos fundiários envolvendo aquelas terras.
} 
da situação dos Arara, ao longo do rio Aripuanã e na cidade de Ariquemes. No relatório apresentado à FUNAI, solicitava-se então a instalação de um posto de vigilância na região, tanto para proteção da população indígena ameaçada pelos latifundiários como para atendimento médico, e a demarcação de uma área no Guariba e outra no Aripuanã. A equipe recenseou 22 famílias Arara, distribuídas pelo beiradão dos rios Aripuanã e Guariba e nas cidades de Aripuanã, Matá-matá e Ariquemes, indicando ainda a existência de outras famílias dispersas ${ }^{30}$.

\begin{abstract}
De um modo geral, a população Arara está inserida nas camadas mais pobres da população do beiradão e da vila de Aripuanã. Trabalham como seringueiros, vendendo sua produção e adquirindo mercadorias dos marreteiros a preços aviltados. Os roçados garantem a subsistência básica do grupo - mandioca, macaxeira, milho, cana, fava e frutas. À pesca, inclusive com atco e flecha, tem importância fundamental na sua dieta alimentar.

As doenças comuns na região, como tuberculose e malária, vêm assolando estes índios, causando mortes periódicas entre eles, uma vez que carecem de qualquer tipo de atendimento médico, valendo-se exclusivamente dos remédios do mato que conhecem. Recentemente, o Arara Goncha, pajé do grupo, faleceu vitimado pela tuberculose. Problemas de aborto entre as mulheres e convulsão nas crianças pequenas, são também corriqueiros. (VALDEZ, 1984)
\end{abstract}

O relatório do missionário alertava ainda que fazendas e colonizadoras - que têm sua origem em grilagens ou são propriedades com titulação irregular, sem exceção - estavam expulsando índios e seringueiros do beiradão, para o que vinham "utilizando serviços de jagunços, fazendo ameaças e, inclusive, tendo por vezes mandado queimar casas". Um dos jagunços mais conhecidos na região, Joaquim Lima Gomes (vulgo “Joaquinzão"), estava então arranchado na boca do rio Branco, exatamente para impedir o acesso dos Arara às suas terras.

No ano seguinte um novo relatório foi encaminhado pelo CIMI ao órgão indigenista oficial, completando ali os dados do levantamento populacional e detalhando uma proposta de demarcação de quatro áreas descontínuas para os vários agrupamentos Arara. O missionário Valdez relacionou 102 pessoas, distribuídas nos seguintes locais:

- Rio Aripuanã: localidades de Campo Grande, Boca do Piranha, Boca do Pacutinga, Cachoeira dos Veados, Bom Sucesso e foz do rio Branco;

- Rio Guariba: localidades de Ronca e igarapé Pajurá;

- Cidades: Aripuanã e Cuiabá (MT), Manaus, Humaitá e Matá-matá (AM) e Ariquemes e Porto Velho (RO).

Conforme advertia o missionário, a situação dos Arara agravava-se: duas famílias que moravam acima da boca do Canumã, no rio Aripuanã, haviam sido expulsas de sua colocação por pistoleiros e policiais, estes queimaram suas casas e todos os seus pertences (VALDEZ, 1985). E em março de 1986, o CIMI enviou mais um relatório à FUNAI denunciando a violência contra os índios e os seringueiros e a ocupação acelerada de suas terras por latifundiários, ações estas que contavam com a cumplicidade do então governador Júlio Campos (VALDEZ, 1986). E alertava que os Arara exigiam a demarcação de suas terras: "Garantem que não vão sair para parte alguma, apesar das pressões que sofrem".

A despeito da gravidade da situação local, somente em abril de 1987 foi lançado a campo um Grupo de Trabalho da FUNAI para estudo da área dos Arara, com vistas à sua identificação e delimitação (Portarias PS 1761/86 e 515/87/2a 
SUER/FUNAI). Coordenado pela antropóloga Vera Lopes dos Santos da $2^{\circ} \mathrm{Su}-$ perintendência da FUNAI, o GT realizou um levantamento da população Arara e um reconhecimento de seu território, reunindo dados históricos e socioeconômicos para fundamentar a proposta de interdição de 242 mil hectares situados entre os rios Aripuanã e Guariba, englobando o rio Branco e os igarapés Moacir e Novo. Resguardando os sítios tradicionais onde viveram até há poucos anos e não registrando qualquer ocupação de vulto por não-índios, a área então denominada "Arara Beiradão" estava apta a receber os Arara de volta, desde que houvesse o apoio institucional do órgão indigenista, segundo a proposta da antropóloga (SANTOS, 1987).

O levantamento fundiário, peça processual que obrigatoriamente deve complementar o trabalho de identificação de uma área indígena, causou, entretanto, um verdadeiro espanto, pois encontrou um total de 68 títulos de propriedade que incidiam na área proposta. As terras, como se soube depois, haviam sido loteadas e vendidas pelo Instituto de Terras do Estado de Mato Grosso - INTERMAT, em março daquele mesmo ano, nos últimos dias, portanto, do Governo Wilmar Peres, vice-governador que substituiu o renunciante Júlio Campos. Ficou evidenciado, além de tudo, o favorecimento ilícito que comandou tais transações: o antigo cemitério dos Arara, na margem direita do rio Branco, restou dentro de um dos maiores lotes, entregue a Luiz de Almeida, um ex-advogado do próprio INTERMAT. Das terras do rio Branco, por sua vez, uma boa parte havia sido dividida diretamente pelo empresário Marinho Brandão (Organização de Terras Brasil Norte) em glebas de mais de 20 mil hectares cada, e estavam agora nas mãos de Esthil Móveis e Decorações, da agropecuária Thomagran e de Antônio Dirceu Deboni.

Com sua área totalmente retalhada, os Arara aguardavam, desolados, as iniciativas e promessas da FUNAI.

\section{Longe da terra prometida}

No mês de novembro daquele mesmo ano, a FUNAI, finalmente, movimentou-se, mas, infelizmente, de maneira bastante atabalhoada. Um funcionário da Administração Regional de Vilhena, Paulo Oliveira, lotado em Castanheira (MT), tramou a ocupação das margens do rio Branco, ao sul do paralelo 10, contando para isso com os Arara que moravam na cidade de Aripuanã e com a ajuda dos Cinta Larga. A iniciativa, como se soube mais tarde, incluía também negócios com o garimpeiro "Bené", que explorava o garimpo Ouro Preto em terras dos Cinta Larga, e com a Madeireira da Paz, de Antônio Filho, os quais ofereceram o apoio logístico para a movimentação. Alegando depois que se equivocara na leitura do mapa, ao confundir os pontos cardeais, o funcionário da FUNAI conduziu os Arara a um conflito fora da área proposta pelo GT. Aquele trecho de terras, a ser desmembrado da área indígena Aripuanã, mas ainda resguardado pela Portaria 562/N (FUNAI, 14/03/79), estava sendo ocupado por posseiros e grileiros, alguns inclusive mancomunados com autoridades municipais.

A mando do funcionário Oliveira, os Arara e os Cinta Larga forçaram a retirada de 57 posseiros, provocando com isso a reação dos grileiros, entre os quais se destacava o delegado José Bento, da Polícia local. O fato ganhou ampla repercussão nos jornais de Cuiabá, contudo com informações desencontradas repassadas pela assessoria de imprensa da própria FUNAI31.

${ }^{31}$ Ver por exemplo: Diário de Cuiabá, 21/11/87 (“Invasores atacam índios na região norte do Estado”); e Jornal do Dia, 22/11/1987 ("Invasores fortemente armados atacam índios na região de Aripuanã") e 24/11/1987 ("Delegado de polícia de 
Com a confusão armada, o órgão indigenista promoveu mais uma de suas “operações”, já que o novo superintendente regional, Nilson Campos Moreira, desejava ardentemente mostrar serviço. No dia 20 de novembro a cidade de Aripuanã estava em polvorosa: liderada por Campos e pelo indigenista José Eduardo, este da ADR de Vilhena, chegara a caravana da FUNAI composta por policiais federais fortemente armados, por representantes do INTERMAT, pelo delegado Ronaldo Osmar, de Juína, e por um índio Nambikwara que vinha conversar com os "parentes" indígenas. A rápida vistoria que fizeram na área pôs a nu o processo de grilagem em curso: os policiais fizeram questão de trazer, como prova, um tronco de árvore onde se lia "Área do Delegado". ${ }^{2}$

Na noite seguinte as autoridades convidaram a população para uma reunião na Câmara dos Vereadores, onde o superintendente da FUNAI afirmou que o órgão tinha por objetivo trazer a "paz social" e que, embora reconhecendo os erros do funcionário Paulo Oliveira, seus atos teriam, contudo, permitido desvendar as transações que envolviam a área interditada. Comprometeu-se então a estudar com o INTERMAT e a Secretaria de Assuntos Fundiários do Estado o assentamento de trabalhadores sem-terra na área a ser liberada - cerca de 100 mil hectares. Por fim, os representantes da FUNAI sublinharam o direito dos Arara a terem acesso às terras do rio Branco, seu habitat tradicional. Encerrada a reunião, funcionários e policiais foram participar de um churrasco no restaurante Panelão, regado a uísque Natu Nobilis, como se ali estivessem selando, em clima festivo, o dito compromisso com a tranquilidade social - e aproveitaram para, ao mesmo tempo, comemorar o aniversário naquele dia do superintendente da FUNAI...

Soube-se depois que o presidente da FUNAI, Romero Jucá, havia assinado uma portaria de interdição da área indígena Arara Beiradão (PP 3.831, de 20/11/1987, publicada no D.O.U. em 01/03/1988). A situação dos Arara, porém, não melhorou, ao contrário: contratado pela madeireira Esthil, o capataz Joaquinzão passou a dirigir, como medida preventiva, seguidas ameaças, principalmente à família de Rodrigo e Anita Vela. "Podem subir o rio Branco, mas vão descer de bubuia”, isto é, mortos, alardeava o pistoleiro. No beiradão do rio Aripuanã cerca de vinte famílias indígenas estavam dispostas a retornar ao rio Branco, mas, amedrontadas, aguardavam um apoio efetivo da FUNAI: "Oh, vocês que são grande, vocês que são metido a grande é que devem tomar providência aqui. Vocês têm força, e eu não tenho", apelavam eles (PORANTIM, 1988).

Mas as promessas se repetiam, monotonamente, solapando cada vez mais o ânimo e as esperanças dos Arara. O superintendente da FUNAI retomou a Aripuanã no dia 7 de setembro de 1987, desta vez acompanhado pelo secretário de Assuntos Fundiários do Estado, Edgard Nogueira Borges, para mais uma reunião pública acerca das terras que seriam liberadas ao sul do paralelo 10. A presença deles havia sido solicitada pelo próprio prefeito municipal para, segundo disse então, esclarecer as acusações que vinham recaindo sobre a Prefeitura. Tratavase, porém, de um esforço, acima de tudo, para restaurar a credibilidade do PMDB local, tremendamente fraturado pela disputa entre facções, as denúncias de corrupção e o envolvimento em conflitos de terra. Quanto aos Arara, o superintendente alegou falta de recursos para o deslocamento de um funcionário e a instalação do posto da FUNAI na área. Prometeu, contudo, a elaboração de um "projeto de assentamento", a ser efetivado no máximo dentro de três meses.

Aripuanã comandou ataque aos índios Arara”).

${ }^{32}$ Com tudo isto, embora contasse com o apoio do prefeito Almiro Willig, o delegado José Bento foi destituído do cargo pelo delegado geral da Polícia Civil do Estado. 
Mas os meses passaram enquanto os Arara esperavam pela FUNAI. Em julho de 1988, todavia, alguns portadores de títulos concedidos pelo INTERMAT impetraram um "mandado de segurança" na $8^{\circ}$ Vara da Justiça Federal, em Brasília, pretendendo anular a Portaria que interditou a área Arara Beiradão, sob alegação de que a FUNAI não teria autoridade legal para obstruir o acesso a suas "propriedades". Na prática, eram apenas os próprios Arara que não conseguiam regressar ao rio Branco, pois os pretensos proprietários já haviam iniciado a ocupação da área, fazendo derrubadas, plantando capim e erguendo benfeitorias.

Inconformados, Rodrigo e Anita viajaram para Brasília no final de julho e realizaram uma verdadeira peregrinação pelos órgãos públicos em busca de uma solução para as terras do seu povo. Ouviram novas promessas, aceitaram novos prazos.

Afinal, a $2^{\circ}$ Superintendência da FUNAI constituiu um Grupo de Trabalho Especial (Portarias PS 551, de 14/07/1988, e PS 557, de 26/07/1988), coordenado pelo sociólogo José Augusto Mafra dos Santos e composto também por representantes da Secretaria de Assuntos Fundiários e da Polícia Federal, com a "finalidade específica de elaborar o programa de assentamento da Comunidade Indígena Arara-Beiradão". No mês de agosto o GTE percorreu, mais uma vez, as casas, os rios e as colocações dos Arara. No dia 23 daquele mês seus componentes reuniram-se com os "representantes" da comunidade indígena - o "cacique" José Rodrigo e sua esposa Anita e duas outras famílias -, na presença ainda do pároco padre Duílio e da religiosa irmã Lourdes Christ, da igreja católica local. Na ata assinada pelos membros do GTE e pelos índios consta que estes concordavam com o "assentamento" em uma área do rio Branco calculada em 43.050 hectares.

Uma das componentes daquele Grupo de Trabalho, a antropóloga Dêidi Luci da Silva, entretanto, se recusou a assinar a ata da reunião e elaborou um relatório em separado, assinalando que a decisão foi imposta de forma autoritária aos Arara. Segundo ela, tal proposta teria vindo pronta da $2^{\circ}$ Superintendência, e a viagem do GTE seria apenas um subterfúgio para fundamentar a redução das terras dos Arara a duas pequenas áreas, uma no rio Branco e outra no Guariba, que juntas não somariam 70 mil hectares. Mas como os índios do Guariba não concordaram em sair de suas colocações para a área proposta, restou apenas o trecho do rio Branco para as gestões do coordenador do GTE (SILVA, 1988). A antropóloga denunciou ainda que aquela proposta desconsiderava a existência comprovada, na área interditada, de um grupo indígena ainda isolado - os chamados "Baixinhos" ou "Cabeça Vermelha" - que ficariam desprotegidos com a redução da área.

Reduzir a área, contudo, não seria o único objetivo da FUNAI no caso. O relatório elaborado pelo sociólogo Mafra dos Santos representa, de fato, uma distorção temerária das finalidades originais do GTE: ao invés de um plano para reassentar os Arara, como requeriam as Portarias que constituíram o Grupo de Trabalho, o dito sociólogo veio propor, porém, a demarcação de uma "reserva indígena"33 . Ou seja, para Mafra dos Santos os índios Arara já não teriam quaisquer direitos sobre as terras donde foram expulsos, e por esta razão a FUNAI deveria promover a desapropriação de uma área para então assentá-los.

É uma "nova sociologia", como a denominei, tanto por seus objetivos como

${ }_{33}$ A diferença é que, pelo Estatuto do Índio (Lei 5.001/73), uma área indígena, embora seja inscrita como bem inalienável da União, corresponde às terras ocupadas tradicionalmente pelos índios, aos quais cabe a posse e o usufruto, já uma reserva indígena trata-se apenas de uma área destinada pela União para servir de habitat aos índios. Que provavelmente precisaria ser desapropriada antes de entregue aos índios. 
por seus métodos: ao desconhecer as condições históricas concretas em que viveram e vivem os Arara, nada mais faz que demonstrar suas preferências e, de maneira acrítica mas não desinteressada, acolher como legítimos os resultados sociais da grilagem violenta, da especulação imobiliária e das negociatas governamentais. Ou como justificou num rompante sincero o próprio sociólogo da FUNAI aos índios Arara, resumindo assim os postulados que a embasam: esta é " $a$ lógica do branco; os índios foram vencidos, gente!”

E assim teremos como corolário concreto desta posição, que os parcos recursos da FUNAI, longe de apoiar o regresso dos Arara às suas terras, deveriam ser repassados para fins de desapropriação aos pretensos proprietários da área - grileiros, especuladores, madeireiros.

Para tanto, o sociólogo, através de inacreditáveis malabarismos retóricos, fez de tudo para desclassificar os Arara enquanto grupo étnico, lançando mão de argumentos substancialistas e, sobretudo, parciais: segundo ele, a miscigenação, a dispersão e a dominação teriam rompido o "elo étnico", e assim o "exercício da identidade étnica" pelos seus membros ocorreria tão-somente através da "invocação do passado", uma vez que não compartilhariam mais valores culturais ou uma organização social própria. Fora de suas terras, "mesclados" e com hábitos culturais "exógenos", como os descreve Mafra dos Santos, os Arara sequer teriam lugar na cartilha étnica da FUNAI: na falta de um conceito34 para caracterizá-los, o sociólogo acaba por inventar até mesmo um neologismo - "índios dessituacionados", que traduz por ausentes de "situação étnica”. Melhor dizendo, não seriam mais índios! Ou, na expressão coloquial daquele servidor da FUNAI, referida acima, à "lógica do branco" teria vencido e ponto final.

Mas esta não é apenas, como se poderia pensar, uma "sociologia" a partir da ótica dos vencedores. $\mathrm{O}$ acento dado à situação de miscigenação ou à quase ausência, como diz ele em seu relatório, de "famílias integrais" entre os Arara acaba por revelar a identidade ideológica entre os argumentos de Mafra dos Santos e as teses racistas esposadas pelo coronel Zanoni Hausen anos atrás, que, na condição de diretor da FUNAI, se empenhou em validar uns tais "critérios de indianidade" contra os povos indígenas no Nordeste. Vale lembrar, desta maneira, a crítica que os antropólogos fizeram na época à falsa cientificidade de tais critérios, crítica esta consolidada em vários artigos e pareceres.

A professora Manuela Carneiro da Cunha, por exemplo, apoiada em formulações do antropólogo norueguês Frederik Barth e de outros, mostrou que a identidade étnica não se sustenta em quaisquer critérios raciais e nem mesmo em formas culturais inalteradas: "a antropologia social", diz ela, "chegou à conclusão de que os grupos étnicos só podem ser caracterizados pela própria distinção que eles percebem entre eles próprios e os outros grupos com os quais interagem" (CARNEIRO DA CUNHA, 1981).

Como já se evidenciou na ocasião, atitude que agora se repete, a ênfase classificatória do indigenismo oficial - com seus graus de integração, seus critérios de indianidade ou de situação étnica - responde antes de tudo às tentativas de descaracterizar os índios enquanto índios. O objetivo precípuo, na verdade, seria retirar a legitimidade dos seus direitos e de suas reivindicações territoriais. E desta maneira, esta "nova sociologia" da FUNAI não faz aqui senão o velho jogo sujo dos espoliadores de terras indígenas de todos os tempos: a negação do outro, sua eliminação ideológica, quando não física.

${ }_{34}$ Convém lembrar que as categorias isolados, contato intermitente, contato permanente e integrados foram propostas por Darcy Ribeiro para a análise das etapas de integração ou, como diz este autor, do processo de transfiguração étnica que ocorre no enfrentamento entre os índios e a civilização (RIBEIRO, 1982). Estas definições, inclusive, se tornaram conceitos jurídicos, ao serem posteriormente incorporadas pelos legisladores ao Estatuto do Indio. 
Os índios Arara permaneceram, apesar de tudo, como um problema real, alheios aos malabarismos conceituais do sociólogo de plantão e de outros zeladores dos interesses anti-indígenas. Em maio de 1989 eles, mais uma vez, retornaram a Cuiabá e foram bater na porta da FUNAI: vieram reclamar uma solução, pois queriam retornar para o rio Branco...

\section{Capítulo 3 A Voz da Memória}

As entrevistas, a seguir, de personagens variados (índios, seringueiros, empreiteiro etc.), foram realizadas em momentos e circunstâncias e por interlocutores diversos. Cada uma delas, assim me pareceu, pode ser apresentada como um desses retalhos da memória, ao mesmo tempo social e individual. Reunidas aqui, talvez possam compor, em cores e tons muito singulares, um quadro etnográfico dos grupos indígenas do Guariba e do rio Branco, uma certa trajetória histórica e um perfil socioeconômico dos que então foram designados e hoje se designam pelo etnônimo Arara.

\section{Cada tribo tem um sistema}

Conheci e entrevistei o ex-seringueiro Raimundo Santos em sua casa, na ponte do Guariba, por ocasião de uma viagem de pesquisa promovida pelo GERA/UFMT, no dia 1 de julho de 1991.

Raimundo: Já vou fazer 71 anos no dia 12 de setembro. Estou com 52 anos só aqui no Guariba. Nasci no rio Roosevelt, acima de Vera Cruz - essa cachoeira é muito grande, conhecida por Doze Tombos, são doze quedas d'água debaixo do céu. Acima dessa Doze Tombos... eu não sei o nome da colocação, não me lembro. É mais ou menos uma hora de motor-rabeta acima dessa Doze Tombos. Esse Valter [Santos], meu irmão, nasceu na boca do rio Branco [do Roosevelt]. Eu vim primeiro que ele para o Guariba, mas depois eu saí, fui para Manaus. Foi o tempo que me casei. Casei já velho, quase pegando 40 anos. Nasceu o primeiro filho e fomos para Manaus. Passei 27 anos trabalhando em Manaus, isso numa única firma, trabalhando de empregado. Aí com 27 anos eu fui indenizado, saí e comprei uma casa. Tenho uma casa em Manaus na Dom Pedro I, em frente ao Hospital Tropical. Vim para cá, mas vim só, a família ficou. Trabalhei dois anos e baixei. Eu era aviado da firma... não-sei-quê Schuam, um turco. Aí baixei para Manaus, passei três anos mais. Quando subi já vim com a família. A minha filha Socorro já tinha saído do colégio. Eu me coloquei no [lugar] Zé Mulato, abaixo do Xibé um pouco.

Pergunta: O senhor conheceu os Arara aqui no Guariba?

Raimundo: Quando eu cheguei os Arara não moravam mais aqui no Alegria [onde hoje está a ponte do Guariba], tinham saído. Eles estavam mais para cima, num igarapé que chamam Moacir. Esse Moacir pertence aos Arara. Aí morava índio Arara para danar. Aliás, todo mundo gostava dos Arara, eles não eram perseguidores de ninguém. Eles matavam gente sim, mas não era assim. Às vezes matavam porque eram obrigados a matar, mas nunca como esses Orelha de Pau, esses eram uns índios perigosos. O Guariba era a região deles. Parece que foram eliminados, não ouvi mais falar. Eles brigavam muito, os Orelha de Pau, esses Arara, esse Cinta Larga e um tal de Cabeça Seca. 
Pergunta: Quem era o tuxaua dos Arara quando estavam no Moacir?

Raimundo: Nesse tempo era Arimã. Tinha ao menos sessenta a setenta pessoas. A vida deles era botar roça, comer. Não cortavam seringa. Hoje que já tem alguns cortando seringa.

Pergunta: Mas me disseram que quando estava o tuxaua Caetano eles cortavam seringa...

Raimundo: Isso mesmo, Caetano cortou seringa. Foi daí que eles saíram e foram para o Moacir. Esse Caetano eu conheci pessoalmente, ele já era uma pessoa de idade. Não estou lembrado se ele morreu no Moacir ou foi aqui mais para baixo. Ainda tem uma índia velha, dona Júlia, mora aqui para baixo.

Pergunta: A filha de dona Nazaré?

Raimundo: Isso mesmo. Era muito índio Arara. Eu conheci aqui no Roosevelt os primeiros índios que amansaram, eu convivi com eles. A primeira aldeia de índios foi amansada aí pelo finado meu pai, era dos Arara. O tuxaua chamavase Paroné. Eles se acharam perseguidos, esses Orelha de Pau perseguiam muito eles. Aí o tuxaua morreu, ficou a Cassirene, a mulher do tuxaua - ela ficou desorientada, não tinha a base do marido. Paroné era filho do tuxaua, mas era pequeno. Ela ficou como tuxaua e o jeito que teve foi amansar com meu pai. O nome de meu pai era Manoel Vicente dos Santos, era gaúcho. Depois deles amansarem, esse Paroné estava grande, a Cassirene deu... Foi uma coisa linda, eu conto isso porque vi com meus olhos. Uma reunião medonha, tudo quanto era índio, aí bate palma e canta aquelas coisas. O Paroné ia ser o tuxaua da maloca, a Cassirene estava comandando mas achou que tinha que entregar o capacete para o filho. Foi uma festa danada aquele dia, quando ela entregou o capacete para o filho.

Bom, seu menino, pelo amor de Deus! O Paroné matou muito índio: ele tinha raiva de índio, depois que ficou homem ele odiava porque tinham matado o pai dele. Então esses tal de... tinha Cuximiraíba e esses Orelha de Pau. Ele botou para acabar com eles, entrava na aldeia, pegava criança assim pelo mocotó, suspendia de cabeça para baixo e cortava com o terçado. Isso foi no rio Castanho, que o Rondon colocou o nome de Roosevelt.

Pergunta: Esses Arara no Roosevelt tinham outra denominação?

Raimundo: Tem duas tribos de Arara que eu conheci. Tinha o Arara e o Ararabenis. Esse tinha uma listra assim [tatuagem facial], aquilo morre e não se acaba. Os Arara amansaram antes do Rondon passar. Teve uns aí, uns três, que o Rondon levou, ele achou muito inteligentes. Ele não matou índios. Rondon falava tudo que era idioma, chegava e falava com os índios, entrava na aldeia e falava com os índios. Assim, domando para não mexer com os seringueiros. A mortandade era grande. Então, dessa época aí eles fracassaram mais esse negócio de ficar matando gente. Às vezes vinham roubar as coisas da casa, pertences. Roubaram uma vez, me lembro bem, aqui no Aripuanã, eu fui dessa vez numa correria [expedição]. O índio chamava-se Matias. Tinha o Matias, o Adeca e o Orá. O Adeca e o Orá eram os tuxauas dos Arara.

Pergunta: Quais Arara? Do Guariba ou do rio Branco?

Raimundo: Trançavam isso aí tudo. Porque a gente via Arara aqui, via no Roosevelt... 


\section{Pergunta: Mas eram os mesmos?}

Raimundo: Era o mesmo, só distinguia que tinha o Ararabenis e o Arara mesmo. Mas era uma coisa só, tudo unido. Aí nós fomos no igarapé Natalzão, a aldeia deles era para lá. O índio falava tudo. O patrão era dom Raul del Aguila, aí mandou, foi muita gente. Chegou na aldeia, deram uma porção de tiros para o ar, mais de sessenta armas atirando - mas não atirava para ofender os índios. O tuxaua disse: "Aquele que matar índio também cai junto com índio, não tem que atirar no índio". Eu sei que deram um bocado de tiros, os índios alertaram tudo. Aí entramos. Eu sei que traçaram língua para lá, e tudo armado, os índios também, mas não trocaram flecha nem bala. O Adeca mais o Orá entraram na aldeia, a turma ficou de fora. Ficou também um pelotão de índios do lado de fora, tudo armado, com medo do índio entrar e a gente aproveitar para fazer fogo. Aí eles ficaram de prontidão também. Quando eles vieram de lá trouxeram uma malazinha - eles tinham carregado sabe lá de onde - quando foram abrir, arrombaram a mala, tinha um 38 duplo desse tamanho assim. Índio naquele tempo tinha medo de arma, não queria nem ver, se visse um cartucho saía assombrado. E quando viram o revólver, deixaram essa mala para lá, não mexeram. Aí o Adeca trouxe, cheinho de bala. Trouxeram esse revólver e parece que deram para o dom Raul. O Adeca cortou gíria para lá, aquela confusão. Que diabo entendia?

Pergunta: O senhor chegou a aprender alguma palavra?

Raimundo: Não, não aprendi nada. A minha segunda mulher era filha desse tuxaua Adeca. Eles eram uns índios bonitos.

Pergunta: Onde morava o Adeca?

Raimundo: A aldeia deles era entre o Guariba e o Aripuanã, era nesse meio. Eu me juntei com ela, morei três anos. Mas ciúme assim só no inferno, qualquer coisinha ela dizia que matava... Eu já estava querendo escapulir das unhas dela. Tanto o Adeca como o Orá gostavam muito de mim, da minha sogra, mãe dessa minha mulher, gostavam demais. Aí um dia eu falei com o Adeca. Ela chamavase Derazinha, a mãe dela era Derá. Eu contei o caso para ele, ele chamou atenção dela, deu uns conselhos... Ela era bonita, civilizada, mas tinha um sotaque de índio.

Uns índios asseados. Eu dei fé, cada tribo tem um sistema, tem um tratar, tem um sistema de comida. Esses índios Arara, a comida que eles faziam qualquer pessoa podia comer. Uma vez eu botei uma roça aqui no Aripuanã, lá em baixo. Há muitos anos atrás aquilo já tinha sido capoeira de índio. Nós plantando, eu e meu compadre, cavando, aí achei um pão deste tamanho. Bati nele, parecia uma borracha enterrada no chão. Aí ele disse: “O que é isso compadre?” Respondi: “Eu vejo dizer que isso é pão de índio". Ainda lavei assim, pedra não é. "Isso não é batata do mato?" "Não é, vejo dizer desde menino que isso é pão de índio". Deixa para lá. Aí passei aqui para o Guariba. O finado Jerônimo Marinho é que comandava os índios. Trabalhavam com ele, cortavam seringa, esse Caetano. Aí baixaram, vinha o Zé Brasil, Arimã, tinha Marã, Marãzinho e Marã Preto - este era meio moreno -, um tal de Pedro Corobó, tudo índio. Aí o compadre Zeca disse: “Compadre, pergunta se isso é pão?” Disse: “Tá bem!" Aí eu trouxe o pão e disse: “Éh Zé, Zé Brasil! Diga uma coisa, isso aqui é pão de índio?” Ele falava mas era ruim, algumas coisas a gente entendia. Ele olhou e disse que não sabia. Falei para o compadre Zeca: "Eu não estou lhe dizendo que isso é troço que nasce do chão, eu vejo desde menino". Um bocado deles [índios] amansaram com papai e eu ouvia. Aí virou e mexeu, baixaram outros [índios] com o finado Aleixo, Antônio 
Aleixo de Moura que era também patrão. Eu perguntei para ele [um índio]. Ele olhou: "Não sabe não". Passou-se, passou-se. Aí baixaram do Aripuanã o Adeca, o Orá, o Matias e eu mostrei para eles. Adeca falava bem português, ele não tinha sotaque de índio, a gente notava que ele era índio porque o jeito deles...Eu falei com ele, ele olhou e mostrou para o Orá, "Mas isso é pão de índio?" Ele disse: "É. é pão de índio". Eu disse que tinha perguntado para uma porção, para aqueles do Guariba, para o Zé Brasil, o Pedro Corobó. Ele achou graça e disse: "Ele não sabe falar direito, mas conhece, ele sabe que é de índio. Mas ele disse que não sabe porque cada tribo tem um sistema. Isso é pão de índio, isso pertence a mim" - e bateu no peito. "Isso é nós que fazemos". Uns fazem de milho, outros fazem de macaxeira, outros fazem de mandubi [amendoim] que chamam, outros fazem de cará. Então cada um tem sua qualidade. Ele sabia que era pão de índio, mas ele queria dizer que não era dele, era de outra tribo.

Pergunta: E esse tuxaua Caetano, ele aviava os outros índios?

Raimundo: Isso mesmo, ele tinha barco, recebia mercadoria. Trabalhou aí no [igarapé] Moacir, era instruído pelo finado Jerônimo Marinho, que foi patrão desse Vavá [um seringueiro]. Vavá conta isso muito bem, morou junto com eles. O barracão do Jerônimo Marinho era dentro do Moacir. O Jerônimo Marinho trazia mercadoria do J. Negreiros, e aqui aviava o Caetano e outros. O Caetano trabalhava com meia dúzia de índios e também civilizados. Quando conheci, ele já era meio idoso, ele era gordo, forte. Ele falava bem assim como eu estou falando, mas quando falava o idioma dele, por exemplo quando ia chamar um índio acolá - não tinha diabo que entendesse! Ele teve uma porção de filhos. Quando eu vim de Manaus, ultimamente, tinha dois: um era capitão da Polícia Militar, o outro era cabo. Uma porção deles vive bem, por isso que eles não vieram mais para cá. Eles são gente da farda, e aqueles que não são vivem bem empregado. $\mathrm{O}$ índio tem um cartaz danado, e eles são um povo inteligente.

Pergunta: Do Moacir então estes Arara foram dispersando?

Raimundo: Foi o tempo que o Jerônimo Marinho morreu. Ele era tudo para eles, era o deus dos índios. Como para esse Caetano, o Jerônimo Marinho dava todo apoio aos índios. O Jerônimo Marinho morreu, acabou-se tudo. Foram tudo de águas abaixo. Foi o tempo que o Jerônimo Marinho foi para São Paulo, doente, não tinha mais cura. Ele já tinha ido, depois voltou, veio aqui, balanceando, ele ia entregar isso tudo, consta que ele ia deixar esse Caetano, ia entregar tudo para o Caetano e ia embora. Mas eles estavam tão acostumados, chamavam pai Jerome... Depois que o Jerônimo morreu, desmantelou-se tudo. Esse Caetano estava de rebolada por aí. Ficaram todos desorientados. Acabou-se tudo. Hoje tem alguns deles, índios Arara, mas é pouco. Lá no Aripuanã eu vi um, já velho, a mulher do Matias, Maria Rodrigues. Tem alguns espalhados. Em Manaus tem um bocado deles.

\section{Vestidos de vermelho}

Entrevistei dona Mocinha, ex-moradora do Guariba, na minha casa em Aripuanã, no dia 14 de janeiro de 1987. Dois dos seus filhos foram mortos pelos Cinta Larga em 1971, o que levou a migrar para o rio Aripuanã.

Mocinha: Eu fui nascida no Guariba e lá me criei, num lugar chamado Cachoeira Seca. Meu pai, Teodoro Garrido da Silva, maranhense; minha mãe, Maria 
Lourival dos Santos. Meu nome: Francisca Lourival dos Santos. Desde menina meus pais me apelidaram Mocinha, e foi ficando. Nós trabalhava na Cachoeira, perto do Bacaba. Lá nasci, me criei e criei meus filhos. Só não criei o Garcia porque ele acabou de se criar aqui [em Aripuanã]. No tempo que eu era criança não tinha esse negócio de índio [Cinta Larga], só tinha os Arara para baixo. Depois que me juntei, que subi, que fui trabalhar no Mané José, com o velho Manoel [seu marido], pai do Chicuto, foi que começou a aparecer. Ao lado que eu lavava roupa, ficavam jogando pau, pedra... Era eles [os Cinta Larga] com brincadeira.

Pergunta: A senhora conheceu os Arara no Guariba?

Mocinha: Não, só ouvia falar. Mas teve um bando de Arara lá para o lado do [igarapé] Moacir [afluente do Guariba], e outra turma de Sucuruí [Suruí?], que foi que fez uma turma - dessa que tem ainda uma aí, que é a comadre Maria Xapuri e o compadre Eduardo. Foi desses que eles correram com medo dos Arara é dos Sucuruí. A comadre Maria e o compadre Eduardo - nesse tempo ele era pequeno, só ia nas costas - eles correram com medo dos Arara e Sucuruí que botaram neles para matar, eles correram com medo e se obrigaram a amansar. O finado Jerônimo [Marinho] fazia assim: levava pente vermelho, pano vermelho, toupa vermelha, deixava lá na beira do igarapé para eles. Aí eles levavam aquilo e deixavam para o finado Jerônimo: porco assado, macaco assado. Aí o finado Jerônimo trazia tudinho, era o patrão, ia lá e trazia. A colocação era dentro do Moacir, no barracão dele.

Os parentes da comadre Maria Xapuri, esses que amansaram, eu vi tudinho. Eles usavam só uma cintazinha passada no cós, parece que era de envira, vermelha, com um palmo de largura, dura. Só com a cinta assim, eles saíram tudinho, as caboclas com os cunhãzinhos nas costas, e os caboclos tudo na frente. Os colares deles não cheguei a ver. Vi eles quando chegaram no barracão, aí o finado Jerônimo vestiu tudo, pronto, ficaram tudo vestido. Aí batizaram eles tudo. É porque morreram tudo. Desses caboclos só tem mesmo a comadre Maria Xapuri, o compadre Eduardo, o Antônio - que é filho da comadre Maria com o Antônio Marques, que é civilizado.

Pensei que a dona Nazaré não fosse cabocla não. Eu sei que a dona Maria Xapuri é, porque eu vi quando ela saiu lá do mato e amansou, entrou dentro do barracão do finado Jerônimo. Entraram tudo nu e ele vestiu tudinho. Tinha Apiacá, tinha finada Nazaré, tinha finado Noé, finado Arônio - esses morreram tudo, de gripe, pegaram uma gripe doida, matou eles. Em pouco tempo que eles amansaram, pegaram essa gripe, aí foram morrendo. Eles trabalhavam com o finado Jerônimo. trão?

Pergunta: E esse pessoal que trabalhava com o índio Caetano, que era o pa-

Mocinha: Esses eu não me lembro, só me lembro do finado Jerônimo. que trabalhava no Moacir. Dessas caboclas que amansou, eu sei que está vivo é a comadre Xapuri e a Beatá, que foi para Bolívia com um homem, ela se juntou com um boliviano e foi para lá. Levou até um filho, deste tamanho, chamado Joaquim, Era muito caboclo, era muito.

A Maria Xapuri quando amansou já era mulher, já com filho. Trazia o compadre Eduardo nas costas. Ela amansou solteira, só com o compadre Eduardo nas costas, filho dela. Aí depois que ela amansou, ela se juntou com Antônio Marques. Ele já morreu, é o pai do Antônio. Só mesmo o Antônio, não teve outro. Foi o tempo que ele baixou da Prainha lá para baixo, atacou um reumatismo nele e ele 
morreu.

Pergunta: Será que havia umas cem pessoas no grupo que saiu?

Mocinha: Uns cem índios? Tinha. Amansou bastante, era índio grande, velho, índio que nem esses meninos que têm aqui, molecote assim amansou muito. É que morreu tudo. A gripe é que matou eles, foram morrendo, se acabando os caboclos. Eu ia muito no barracão, e via eles. As mulheres tudo de tanguinha, assim amarrado na barriga, e eles com a tanga assim, do mesmo jeito. Aí entraram no barracão e quando saíram o compadre Jerônimo tinha vestido todos eles, tudo de vermelho.

Quando eles estavam para amansar, é só o que levava para eles no igarapé: levava corte de fazenda para eles, tudo vermelho, levava pente, tudo vermelho, espelho, tudo vermelho. Levava, botava na beira do igarapé, aquele monte para eles, o finado Jerônimo deixava para eles, tudo vermelho: corte de roupa, calça feita vermelha, vestido para cabocla tudo vermelho.

Pergunta: Tinham tatuagens no rosto?

Mocinha: Não vi. Tinha aquele buraquinho no beiço. Eles amansaram porque os outros atacaram eles para matar, e eles correram. Era mais para cima a maloca deles. Devia ser muito em cima, porque fizeram bastante correria [expedições de extermínio] lá e nunca toparam a maloca deles. Quando os índios atacavam lá, eles juntavam de quinze homens, fazia matula de comida e levavam para não fazer fogo no mato e iam fazer correria. Mas nunca chegaram na maloca deles...

Depois que eu me formei é que começou a aparecer os índios [Cinta Larga] roubando as coisas das casas...

\section{O maior matador de índios}

O empreiteiro Gerôncio Nogueira, ex-empregado da firma seringalista Arruda \& Junqueira, foi entrevistado por Inês Hargreaves (Projeto Cinta Larga/OPAN), em Aripuanã, no dia 26 de junho de 1986.

Gerôncio: Eu sou baiano, mas nasci no Paraná. É porque meus pais são baianos, mas eu nasci no Paraná, e me criei mesmo no Estado de Minas e de São Paulo. Depois meu pai foi para Bahia, minha mãe morreu. Depois eu voltei para Minas. Depois que eu vim para Mato Grosso.

Inês: E como você encontrou o [Antônio Mascarenhas] Junqueira?

Gerôncio: Antes de chegar a Cuiabá, eu estava no Mato Grosso do Sul. Eu já estava velhinho - estou com 55 anos. Em Campo Grande eu encontrei um conhecido que era de São Paulo, me disse que tinha um cara lá - o Lebrinha, esse revendendor da Antarctica - que ia abrir uma fazenda, e me chamou para vir com ele. Trabalhei seis anos com ele. Depois disso passei ano e pouco mexendo com um restaurante, mas eu não gosto. Aí me informaram que o Junqueira precisava de alguém para tomar conta de uma propriedade dele. Fui com o Junqueira lá perto de Vilhena. Depois de lá, eu voltei para Cuiabá. Aí o Amaury [Furquim, prefeito nomeado] vinha para Aripuanã, abrir o município, O Junqueira falou de mim para o Amaury. Aí eu vim abrir a picada [a estrada de Vilhena a Fontanillas].

Inês: Encontrei outro dia com um índio Canoeiro em Castanheira, ele me 
disse que trabalhou com o Junqueira...

Gerôncio: Trabalhavam muitos Canoeiro [índios Rikbaktsa] com o Junqueira, mas trabalhavam [também] civilizados. Agora esses uns [índios] vinham [acompanhar as expedições contra aldeias Cinta Larga35] para achar bonito.

Você sabe que o índio, geralmente, uns têm raiva do outro. O maior matador de índios que tinha aqui [em Aripuanã], em 1932, era um índio, filho daquela velha índia, a Guilhermina. Chamava-se Manoel Gonçalves, era índio mesmo, era o maior matador de índios aqui. É pai daquele Osmar. Tem aí uma mulher com nome Rocilda, cujo pai é chamado Osmar, ela é neta dessa Guilhermina. Então, o pai dele foi o cara que mais matou índio aqui. Era índio, filho daquela velha, e foi pegado novo, civilizou, e foi o cara que mais matou índio aqui. Ele perseguia os outros, para matar índio. No tempo aqui em 1932, tinha esse dom Alexandre, ele tinha sessenta homens só para matar índio. Era a vida matando índio...

\section{Ele era acostumado}

Gravei esta conversa com o casal Virgílio Costa Santos é Nazaré Medina Arara no dia 15 de dezembro de 1987 , enquanto ele fabricava uma canoa para os Arara na casa de Anita e Rodrigo Vela, em Aripuanã.

Pergunta: Quando vocês vieram para Aripuanã?

Virgílio: Fazem uns dez anos, aqui morando em Aripuanã.

Nazaré: Pois é, sêo menino, estou com meus filhos tudo espalhados. Manaus, Porto Velho...

Pergunta: A senhora lembra quando seus parentes saíram no seringal?

Nazaré: Não era nascida ainda...

Virgílio: Quando saíram?

Nazaré: O finado Caetano...

Virgílio: Isso aí faz muitos anos... Tinha um bocado, saíam num canto, daí a pouco estavam no outro.

Nazaré: No seringal Dois de Dezembro, até que eles amansaram.

Virgílio: O pessoal tinha medo, não conhecia, não sabia. Porque era perigoso mesmo. Então a turma foi caçando, saía na fala para amansar, mas tinha medo. Até foi, começaram a amansar. Saíram lá no seringal do Moacir, no Outubro, no Igarapezinho. Tem muito lugar de maloca lá.

Nazaré: O barracão do finado Caetano era no Alegria. Ele era o capitão deles.

Virgílio: Eram muitos. Tinha embarcação, descia para Manaus, trazia mercadoria. Ele era acostumado mesmo, no entendimento. Tinha tudo. Mas ele era índio mesmo. Aí foi o tempo que ele morreu, e foi acochando, acochando...

Nazaré: Foram morrendo, até que se acabou tudo, de gripe, de febre. Quando era de primeiro, até que me lembrava bem. Eles caíram doente, morria de dois, três, só de uma vez.

Pergunta: Tem algum parente da senhora que ainda lembra a língua? A senhora lembra?

Nazaré: Só lembro de nomes das coisas. Quando eu era pequenininha, eu ouvia eles conversando assim - menino como tem cabeça boa, assim era eu. Só

${ }^{35}$ Sobre as operações de extermínio promovidas pela firma Arruda \& Junqueira contra aldeias Cinta Larga na região dos rios Aripuanã e Juruena, ver Dal Poz (1994). 
nomes, mas falar mesmo eu não sei.

Pergunta: Eles faziam tatuagem?

Nazaré: Uma linha preta embaixo do nariz, outra pelo queixo. De Jenipapo. Furava o lábio (inferior), e no nariz.

Virgílio: Tinha os Orelha de Pau, porque colocava uma roda de madeira na orelha, Os Arara, por causa das penas de arara. Agora, os Cabeça Seca...

Nazaré: O primeiro marido meu era filho desse finado Caetano. Esses filhos que eu tenho em Manaus são filhos do filho dele, são netos do Caetano. Meu primeiro marido morreu desse negócio de reumatismo. Depois eu casei com o Virgílio. Eu sei que o finado Caetano era Arara, eu só ouvi assim...

\section{"Estão tudo civilizados"}

Entrevistei Virgílio Costa Santos e seu filho Miguel Paulo dos Santos, no dia 21 de dezembro de 1987, em Aripuanã. O assunto principal foram os conflitos entre os seringueiros e os Cinta Larga no Guariba, mas estes comentários me parecem interessantes.

Virgílio: No Guariba, primeiramente quem começou a andar, que o pessoal via muitos vestígios eram esses Orelhas de Pau (Rikbaktsa). Aí depois dos Orelha de Pau é que começou a aparecer os Cinta Larga. Os Orelha de Pau são do Juruena, mas eles andavam por lá tudo. E os Arara, quando amansaram, eu ainda não estava no Guariba quando começou a aparecer muito Arara. Essa família da Nazaré, era em quantidade danada. É que um bocado morreu. E tinha o velho Caetano, era índio mesmo, a velha do velho Caetano era índia também. Tudo era índio mesmo que amansou. Aí tinha os filhos dele, aí já se misturaram. Eles andavam assim pelo mato...

Miguel: Nesse tempo eles eram que nem esses Cinta Larga. Aí foi indo, foi indo, e foram assim se espalhando. Aí ficaram até muitos anos, aí esse pessoal já é manso. Estão tudo civilizados já, têm uns que a gente pensa que não é nem índio.

Virgílio: Esse [primeiro] marido da Nazaré era filho desse velho Caetano, era índio também. Ela era pequenininha quando eles saíram.

Mudaram até os nomes dos mortos! 36 (Entrevista de Ana Anita Vela ao jornal Porantim)

Índios Arara estiveram em Brasília, no dia 21 de julho [de 1988], reivindicando da FUNAI providências no sentido de retirar os invasores da Área Indígena Arara Beiradão, município de Aripuanã (MT). Eles querem voltar para a terra, mas são ameaçados de morte por prepostos de fazendeiros e madeireiros. O capataz da Sthil Móveis e Decorações, conhecido por Joaquinzão, esteve na casa da última familia a deixar a área e afirmou que "podem voltar, mas sair já é outra conversa".

Absurdo, por si só, já é o fato de q povo Arara não poder entrar em sua própria terra; ou como insinuou O capataz, se entrar, morre. Mais absurdo ainda é a colocação de nomes de brancos em sepulturas de índios, usurpando-

${ }^{36}$ Esta entrevista ao jornal Porantim foi publicada na edição de julho/agosto de 1988, p. 14. Agradeço aos seus editores por me autorizarem a republicá-la aqui. 
lhes até os restos mortais de seus parentes, como forma de consolidar o roubo da terra. Ana Anita Arara conta esse e vários outros episódios de um lugar onde, muito mais que a Constituição e o governo do país, vale a lei da bala.

Henrique [Faveiro] queria matar nós, tinha pistoleiro dele atrás de nós. Já está mais de ano. Agora estamos na cidade, no Aripuanã. Rodrigues (o marido) estava com malária, provocando até hepatite. Nós viemos no Aripuanã e, quando voltamos, eles não queria deixar. Expulsou, disse que não tinha direito de entrar. Ele disse "Agora vocês teve o direito, mas não tem mais; quem manda aqui sou eu”. Botou o revólver em cima de nós.

Estamos passando mal. A gente vai entrar para terra alheia, não pode trabalhar. Tudo é dos fazendeiros. Ninguém entre. Viemos aqui atrás desse pessoal da FUNAI para ao menos dar uma força para gente. Tá demais!

Nós tirava seringa na área. Aí o comprador foi embora. Nós ficamos pelejando. Vendia para um, para outro. Henrique era fazendeiro. Tá morto. Ele me prometeu uma bala, Eu disse: "Essa bala, tenho fé em Deus que ainda vai virar para cima de ti”. E virou mesmo,

Essa terra vai ser nossa mesmo. Estavam pesquisando ouro lá dentro, agora pararam. É gente de Brasília, Acharam garimpo dentro da nossa área. Agora, o Joaquinzão diz que não entra ninguém. Nem índio não está podendc entrar. Essa terra aí é comprada. O posto da FUNAI lá de Castanheira não está com nada; já mandei chamar duas vezes. Ele disse para mim: "Faz força, faz força". Oh, vocês que são grande, vocês que são metido a grande é que devem tomar providência aqui. Vocês têm força, e eu não tenho. Vocês têm os guarda-costas de vocês. E eu tenho? A minha vida é só para mim.

Joaquinzão foi lá em casa. Disse para mim: "Se quiser, volta”, ele não empata. Agora eu não sei minha vida lá dentro. Meu filho disse: "Nós custa a se zangar, mas quando bota é para matar. Não é para deixar doente, não. Os caras precisam acertar nós, mas é para matar. Não deixa arriado". Ele disse: “Ah, mas eu não ameaço com ninguém. Tem pistoleiro, jagunço, na estrada". Aí me convidou para comer um pato. Diz que o mais gordo que tiver no terreiro dele, ele mata para $\mathrm{mim}$. Eu, hein? Não vou não. Quer pegar de outro jeito... Depois fica, oferece leite, café. Joaquinzão é falso!

Eu disse para ele: "Tenho até muita vontade de falar com o senhor. O senhor está ameaçando nós por causa da terra". Ele disse: "Não, dona Anita. Deus me livre! Isto eu não faço com vocês. Eu também sou índio. Minha mãe foi pegada de cachorro". Eu disse: "Minha mãe não foi pegada de cachorro, não. Foi amansada".

Eu tenho cemitério lá. É herança da minha mãe. Agora botaram lá uma grade nas catacumbas e assinou como gente branca. Que o cemitério não é de índio. Tudinho com nome de gente branca.

Faz tempo que a FUNAI prometeu fazer limpeza lá. E isto que eu vou falar com eles. Tenho parente que estão trabalhando no garimpo. Até balearam um. Os índios estão pela casa dos outros. Um mora aqui, outro mora no garimpo, e assim. O meu irmão está no garimpo, no Amazonas. Ixê! Muito longe. Esperou, esperou, nada. Ele disse: "A hora que a FUNAI disser que estão aqui, pode me chamar".

Diz que a Sthil já comprou aquela área. Joaquinzão disse: "Isto aqui já é comprado, Nita. Você larga disso, que a Sthil já comprou da FUNAT". Eu quero saber se a FUNAI vendeu mesmo para eles. Pau D'Arco também disse. Eu disse: "Então é por isto que a FUNAI não está ligando mais para nós". 


\section{Capítulo 4 A Terra, a estrada e o progresso}

O futuro dos Arara, ou melhor, a sua forma de expressão étnica responderá, certamente, ao contexto social e econômico que se perfilar na região de Aripuanã. Não se trata, porém, de um destino a priori, sequer um processo inexorável. Em certa medida, depende do que a sociedade brasileira pensa e faz com relação aos índios, além, é claro, do que eles mesmos pensam e buscam para si. E neste sentido, há que nos perguntarmos: o que representam os povos indígenas para o Brasil hoje?

Via de regra, seriam apresentados como selvagens atrasados ou bárbaros atávicos aos quais não restaria mais que duas possibilidades, ou seu desaparecimento do cenário ou sua assimilação aos conquistadores. Sabemos, porém, que, desde os tempos da Colônia, para que tais "prognósticos" se cumprissem, os índios foram dura e cruelmente disputados, quer como simples objetos, para os bandeirantes e afins que os apresavam e escravizavam, quer como seres inertes e ocos, para a Igreja e o Estado que os desciam e reduziam (ou como se diria nos tempos modernos, atraíam e pacificavam) a pretexto de sua catequese e civilização. Isto tudo resultaria, do ponto de vista dos povos nativos, no extermínio ou depopulação, na desorganização social e alienação cultural c na perda territorial e espoliação dos seus recursos naturais. Mas, para a historiografia oficial, os eventos daí decorrentes seriam, de maneira generalizada, enaltecidos enquanto marcos fundamentais no processo de constituição do Estado e da sociedade brasileiros, cm particular a consolidação de seu espaço territorial.

Neste grande enredo, não por acaso, os índios são percebidos tão-somente como personagens secundários e transitórios de nossa história - mesmo por aqueles, apiedados e a eles simpáticos, que os enquadram como as vítimas indefesas de um combate desigual contra um conquistador todo poderoso (MONTEIRO, 1995). Nos dias atuais esta visão do indigenato enquanto uma condição passageira 37 surge nitidamente informada pelo evolucionismo, uma teoria social que no século passado interpretava as diferenças culturais como se fossem defasagens temporais, com base em uma escala ascendente e progressiva a ser fatalmente percorrida pela humanidade em todos os quadrantes. Na verdade, a despeito de seus flagrantes equívocos metodológicos, esta perspectiva evolucionista domina ainda hoje a maioria das nossas opiniões comuns, na medida em que tomamos o progresso e o desenvolvimento como os conceitos chave para explicar todos e quaisquer fenômenos sociais e econômicos. Estes seriam verdadeiros dogmas ou valores sagrados, em nome dos quais tudo é feito, tudo é válido e todos devem se curvar.

$\mathrm{O}$ argumento e seus autores são bastante conhecidos: para os arautos do avanço inarredável do progresso, beneficiários da atual fase da expansão capitalista no país, os índios não passariam de entraves ou obstáculos a este desenvolvimento sem medidas, senão quistos étnicos" ${ }^{38}$ que ameaçariam a propalada segurança nacional...

É preciso, com urgência, romper este bloqueio ideológico que nos impede de visualizar o papel histórico dos povos indígenas na formação do Brasil, e, assim,

\footnotetext{
37 Não se trata apenas de uma opinião ingênua de senso comum, mas compartilhada mesmo por doutos intelectuais, a exemplo de Hélio Jaguaribe que, numa polêmica recente pelos jornais, fez suas as profecias de que os índios não mais existiriam no século XXI...

$3^{8}$ Lembro a propósito as declarações do major-brigadeiro Protásio Lopes de Oliveira, conforme noticiado pelos jornais, urgindo transformação dos índios em "brasileiros convictos", temendo que viessem a formar "quistos étnicos" a ameaçar a integridade do Brasil (PORANTIM, 1980).
} 
promover investigações que os tomem enquanto sujeitos, analisando suas relações nos contextos correspondentes ${ }^{39}$. Uma releitura da história do Brasil, nestes termos, certamente chamaria a atenção para os processos étnicos aí envolvidos. O que nos levaria a vislumbrá-los positivamente também no futuro deste país, de pluralidades étnicas e diversidades culturais extraordinárias.

Examinarei a seguir o que se vem passando em Aripuanã, onde, sintomaticamente, os índios e seus aliados estão sendo colocados como inimigos do "progresso" e da "integração nacional" - ganchos ideológicos que, aqui e em vários outros lugares da Amazônia, se prestam a instrumentalizar a alienação das terras indígenas e dos recursos naturais nelas existentes.

A luta pelas terras do rio Branco, no entanto, tem significado para os Arara uma possibilidade inesperada de rearticulação étnica. Seu foco é, como se viu acima, um espaço territorial extremamente relevante como referencial para a história do grupo. Mas também, um ecossistema abundante em recursos naturais que talvez possibilite melhores condições de vida, uma alternativa ao subemprego urbano e às atividades temporárias em fazendas e garimpos. $\mathrm{O}$ histórico a seguir procura descrever, em termos sumários, o processo de reconquista desta área pelos Arara ${ }^{40}$.

No quadro fundiário, a cada ano, surgiam novos personagens e novas ações tinham curso. Fazendeiros e madeireiros iniciavam derrubadas, abriam picadas, plantavam pastos ou realizavam benfeitorias para assim marcar sua presença e suas atividades na área. A Portaria PP 3.831/87 da FUNAI, que interditou cerca de 243 mil hectares, para "segurança e garantia de vida e bem-estar" dos Arara, havia sido em parte suspensa por decisão da Justiça Federal que, em novembro de 1988, concedeu liminar favorável ao Mandado de Segurança impetrado por Deolindo Gazoli41, um dos proprietários titulados pelo INTERMAT. Este fato incentivou a ação dos demais fazendeiros que, lançando mão de jagunços armados, procuravam controlar o acesso pela foz do rio Branco e pela estrada recentemente aberta.

Os Arara, embora contassem com o apoio firme da Paróquia católica e do CIMI, permaneciam acuados na cidade de Aripuanã. Insistiam, entretanto, para que a FUNAI os apoiasse com funcionários e policiais, de modo a viabilizar o retorno e reassentamento na área do rio Branco. As autoridades locais, por sua vez, resistiam à demarcação de uma nova área indígena no Município, o qual já abrigava as áreas dos Zoró e dos Cinta Larga. O então prefeito Darcy Laux fazia nessa altura planos para, no jargão local, "tirar Aripuanã do final da linha": a construção de uma estrada que, passando ao norte da área dos Cinta Larga e cruzando pela área Arara interditada, servisse como ligação entre a sede municipal e Ji-Paraná, em Rondônia, atendendo assim a certos fazendeiros e a muitos especuladores (HARGREAVES, 1989). Em junho de 1989 alguns destes propuseram, por ocasião de uma reunião com a presença de autoridades estaduais, doar combustível para que a prefeitura levasse adiante a abertura da estrada. E foi aprovada uma lei municipal que autorizava o poder executivo municipal a abrir uma rodovia pelo interior da área interditada, com a extensão de 150 quilômetros, em direção ao Projeto de colonização Filinto Miller.

Numa primeira tentativa dos Arara para forçar sua volta ao rio Branco, as famílias de Chico e Raimundo e de Nazareno e Maria das Graças Arara fizeram,

\footnotetext{
39 Para os argumentos que fundamentam esta sugestão metodológica, ver John Monteiro (1995).

40 Para a elaboração deste Capítulo, utilizei largamente os relatórios da irmã Lourdes Christ, da equipe do CIMI em Aripuanã, que os acompanha com grande dedicação há vários anos (ver CIMI, 1991, 1992a, 1992b, 1992, 1992d e 1994).

${ }_{41}^{1}$ Esta liminar foi revogada em 1992.
} 
em 1989, uma pequena derrubada e um barraco, mas souberam de novas ameaças do pistoleiro Joaquinzão e se retiraram. Em julho de 1991, alguns Arara entraram clandestinamente na área e foram visitar o local da antiga aldeia no Capivara. Ali roçaram cerca de meio hectare, onde pretendiam plantar. Só puderam entrar às claras na área quando, no segundo semestre do mesmo ano, acompanharam um novo Grupo de Trabalho da FUNAI (Portarias PP 1.046 e 1.193/91) que iria promover "estudos de adequação de limites". Aproveitaram a ocasião para queimar o que havia sido roçado no Capivara e iniciar o plantio de mandioca e milho.

Acerca deste GT, duas me parecem as razões para modificarem os limites territoriais anteriormente interditados: primeiro, uma contundente pressão dos que foram contemplados com títulos pelo INTERMAT 42 e, segundo, o jogo de interesses dentro da própria FUNAI, concretizado nas propostas discordantes emanadas dos estudos anteriores 43 . O trabalho de campo foi efetuado em fins de outubro e permitiu aos Arara rever vários dos sítios onde tiveram suas aldeias. Conduzida por eles, a antropóloga Sheila Guimarães Sá, do Museu do Índio (Rio de Janeiro), testemunhou os vestígios da antiga ocupação indígena ao longo do rio Branco:

Destacamos o cemitério do povo Arara que se encontra na margem direita do Rio Branco, na Antiga Aldeia do Veadinho, as velhas árvores frutíferas (mangueiras e goiabeiras), também encontradas na antiga Aldeia da Volta Grande, e os restos de esteios das antigas casas da Aldeia que lá se encontram. O forno e os utensílios que lá permanecem cobertos pela vegetação nativa. (SÁ, 1991: 13)

Por sua vez, verificou que, em toda a região do rio Branco, a única atividade econômica efetiva era a derrubada e retirada de madeiras nobres (mogno, cerejeira e cedro):

As madeireiras, dando prosseguimento à estrada de chão aberta pela Prefeitura de Aripuanã construíram a partir das margens do rio Branco mais $12 \mathrm{~km}$ de estrada, propiciando uma retirada de aproximadamente três caminhões diários (cada caminhão transporta em média mais ou menos 20 metros cúbicos de madeira) somente neste ano. As esplanadas, conforme constatamos, estavam cheias de mogno e cerejeira. A estrada dos madeireiros a partir de uma bifurcação anterior à Pista do Leão atingiu as cabeceiras do Igarapé Veado Grande, que desemboca no rio Branco. (SÁ, 1991: 14)

Este GT elaborou uma nova proposta de delimitação para a área Arara do Rio Branco, tendo como perspectiva agilizar sua demarcação e pôr um fim no que considerou "uma situação de exílio, miséria e morte" a que estavam os Arara submetidos na cidade de Aripuanã (SÁ, 1991: 27). Para isto, não considerou as informações sobre índios arredios na região ou sequer se prendeu à questão dos descendentes Arara ao longo do Guariba44, antes procurou uma "conciliação de interesses conflitivos", que permitisse inclusive uma alternativa para a redefinição do trajeto da estrada para o Projeto Filinto Miller. Alguns outros critérios, definidos pelos próprios Arara, teriam também norteado a proposta que reduzia a área à metade (de 243 mil para 122 mil hectares): a inclusão de certos lugares de ocupação tradicional, a exemplo do cemitério no igarapé Veadinho, na mar-

\footnotetext{
$4^{2} \mathrm{Na}$ opinião de um advogado que levantou a situação cartorial dos 68 títulos incidentes na área interditada: "É importante salientar o óbvio: os títulos foram doados aos amigos do governo Júlio Campos e Wilmar Peres. Estes amigos não são agricultores e tampouco têm interesses em terra. A eles só interessavam as facilidades documentais e a posterior especulação. Até à época do levantamento judiciário que precedeu a interdição não havia uma única alma de algum destes proprietários ou de alguém a seu serviço em toda a extensão interditada" (apud CIMI 1991).

43 O GT de 1987 foi coordenado pela antropóloga Vera Lopes dos Santos, e o GTE de 1988, pelo sociólogo Mafra dos Santos. $44 \mathrm{O}$ relatório final do GT recomenda à direção da FUNAI, diante disto, a realização de estudos específicos para subsidiar uma proposta de área para os Arara do Guariba e a formação de uma equipe da Coordenadoria de Índios Isolados para localização de um grupo conhecido por "Baixinhos", nas cabeceiras do igarapé Encrenca, afluente do Aripuanã (SÁ, 1991: 32).
} 
gem direita do rio Branco, e várias outras aldeias antigas; a localização de recursos econômicos que anteriormente exploravam, como os seringais nativos, a castanha e à copaíba; a preservação das zonas de caça; a conservação da pesca e a proteção das margens do rio Branco. Os limites, desta maneira, traduziram as reivindicações das famílias Arara que lutavam para refazer sua vida no rio Branco: ao norte, o igarapé Caniço; a leste, o rio Aripuanã; ao sul, o igarapé Encrenca (ou Taboca); e, a oeste, uma linha seca ligando este igarapé ao Caniço (SÁ, 1991: 27-31).

O ano de 1992 foi, porém, repleto de ameaças às famílias Arara na cidade, bem como aos membros da igreja católica e do Sindicato de Trabalhadores Rurais que os apoiavam. A todo momento eram assediados na rua ou em casa e advertidos para que desistissem da área do rio Branco. Alguns destes fatos foram notificados na Delegacia de Polícia local, apontando como autores Joaquim Lima Gomes. Juarez Fernandes e o madeireiro Célio Gomes Henrique (CIMI, 1992d).

No dia 23 de junho o ex-advogado do INTERMAT Luiz de Almeida, um dos favorecidos no loteamento que o órgão fez das terras do rio Branco, se apresentando como "amigo do governador" (Jaime Campos), promoveu uma reunião na Câmara dos Vereadores de Aripuanã, com grande repercussão local. Ali defendeu a construção da estrada para o Guariba: "O rio Branco é minério, é mogno, é peixe; é a espinha dorsal do desenvolvimento de Aripuanã”. E argumentou que os Arara não passavam de "beiradeiros”, para os quais iria obter 20 lotes na Gleba Lontra (onde estão os colonos que foram retirados da área indígena Zoró):

\begin{abstract}
Eles podem se sustentar lá e viver aqui. Podem ir e vir todos os dias, nem precisam tirar os filhos da escola. Aqui não há índios Arara. Não tem índio, só descendentes e devem ser só dois que são na verdade índios mesmo. Já tem mais de vinte anos que não tem ninguém lá. E se invadirem vão levar tiros, porque lá é propriedade privada. Todos se dizem índio, até eu sou descendente de índio Bororo. Esta área era seringal e nunca foi de índio. (CIMI, 1992d)
\end{abstract}

Em julho daquele ano um motor-rabeta emprestado pela Paróquia local aos Arara foi misteriosamente incendiado no quintal da casa de Rodrigo e Anita Vela. E um correntão foi colocado na estrada que leva ao rio Branco, a trinta quilômetros de distância da cidade.

Embora as pressões se intensificassem, também crescia o ânimo das famílias Arara. No segundo semestre o CIMI e a Paróquia iniciaram uma campanha de apoio e solidariedade aos Arara, divulgando sua luta para a reconquista das terras. E em setembro os Arara decidiram, em assembleia, marcar seu retorno à área para o último dia do mês seguinte. Para isso, comunicaram-se com a FUNAI, o IBAMA, a Polícia Federal etc. Porém, estes não se mexeram e os Arara, esperando a colaboração dos órgãos oficiais, protelaram inutilmente a data marcada. Junto com a irmã Lourdes Christ, foram então convidar representantes de várias aldeias Nambikwara e dos Cinta Larga e também Manoel Valdez, ex-missionário que havia realizado os primeiros levantamentos da situação destes índios 45 .

Em meados de novembro em Aripuanã, os índios e os indigenistas planejaram o retorno dos Arara às suas terras. A estratégia meticulosa foi cercada de cuidados:

\footnotetext{
Agora vamos para ganhar a questão, por isso tem que pensar bem. O branco vai ver que nós sabemos agir também. Ele vai dizer: "Índio tem mais inteligência que nós". Tiroteio lá dentro do mato não dá. Não pode deixar atirar. Precisa pensar muito para não ter conflito. Depois de ganhar a vitória, não dá para deixar o nosso parente lá sozinho e ir embora. E número pequeno. Não podemos levar e soltar lá. Podemos formar grupos de seis para revezar, até acalmar. (CIMI, 1992b)
} 
Durante estes dias em Aripuanã, os índios insistiram com a FUNAI, solicitaram segurança à Polícia Federal e pressionaram de todas as formas os governos estadual e federal através de contatos telefônicos e documentos. Nos intervalos, os índios confeccionavam arcos e flechas, supervisionados por peritos cintalarga, atividade que atraiu inclusive os mais jovens. E Anita Vela fazia cocares e braçadeiras, como os que usavam antigamente.

Tais episódios conformam certamente uma arena de luta tanto política quanto simbólica, muito semelhante à de tantos outros remanescentes indígenas no Brasil ${ }^{46}$. De um lado, selecionando itens culturais que sustentassem, diante deles e da sociedade brasileira, sua afirmação de uma identidade indígena; de outro, um processo de mobilização intensa para fazer valer direitos e reivindicações, cujo alvo principal são as autoridades governamentais (tecnicamente falando, $o$ Estado).

A FUNAI, entretanto, pedia que esperassem. Mas os fazendeiros se preparavam e espalharam boatos pela cidade, dizendo que haviam comprado armas e contratado mais quarenta pistoleiros. Segundo o jornal Porantim (1992), o secretário do CIMI, Francisco Loebens, teria comunicado ao Ministro da Justiça Maurício Corrêa que os Arara pretendiam reocupar seu território e havia risco de um confronto armado. Quatro dias depois o Ministro assinaria a Portaria 569, delimitando a área Arara do Rio Branco, segundo os limites propostos pelo último GT da FUNAI.

Este fato animou ainda mais os índios reunidos em Aripuanã. Mas logo souberam que, mesmo com a portaria em mãos, nem a FUNAI nem a Polícia Federal, em greve, iriam acompanhá-los... Os índios entregaram cópias da portaria ao prefeito, ao delegado e aos mandantes dos pistoleiros e marcaram um prazo de quarenta e oito horas. Na véspera da partida, pintaram-se e dançaram. Era a madrugada do dia 28 de novembro: partiram em comitiva duas camionetes e um caminhão - dezoito Nambikwara, onze Cinta Larga e trinta Arara, destes somente uma mulher, a líder Anita Vela. Além deles, o pároco padre Mário Guinzone, Manoel Valdez, da APARAI, José Bassegio, coordenador do CIMI-RO, e Neuri e Solange, da equipe do CIMI local.

A comitiva cruzou a ponte recém-construída sobre o rio Aripuanã e não foi obstruída no correntão: adiante, afastou toras que bloqueavam a estrada47. Chegando às margens do rio Branco, alguns índios desceram de canoa até o Capivara, onde ficariam, e outros foram a pé. Os demais retornaram a Aripuanã. A estes, os pistoleiros ameaçaram parar no correntão, mas desistiram quando os Cinta Larga preparavam seus arcos e flechas na carroceria do caminhão.

$\mathrm{Na}$ cidade as atenções estavam voltadas para a caravana do governador Jaime Campos que inaugurava algumas obras, entre as quais a ponte sobre o rio Aripuanã. Uma comissão pediu-lhe uma audiência e relatou os fatos, requerendo segurança para os Arara. E ao prefeito, ao delegado e ao próprio capataz Joaquinzão, disseram os caciques Naki, Zé Lopes e Constantino, dos Cinta Larga; "Agora é terra de parente Arara. Não mexer mais. Branco não passar mais" (CIMI, 1992b).

Dias depois os Cinta Larga foram acompanhar dois homens e algumas mulheres Arara que iam para a aldeia no Capivara e trouxeram os Nambikwara que lá haviam permanecido. Tinha início, neste momento, uma nova fase na vida dos

46 Entre tantos exemplos, o caso dos Tapeba no Ceará me parece o mais exemplar (ver BARRETO FILHO, s/d).

47 No dia anterior os índios haviam pintado três canoas $€$ isto talvez tenha deslocado a atenção dos pistoleiros para a foz do rio Branco. 
Arara, um passo decisivo para sua reorganização social.

Este fato contrariava interesses políticos e econômicos diversos, não apenas daqueles proprietários que tinham títulos incidentes na área agora delimitada e ocupada, mas também a Luiz de Almeida, Mário Conselvan e outros que pressionavam para que a estrada atravessasse a área indígena e abrisse estrategicamente a região à especulação fundiária, à devastação madeireira e à exploração dos recursos minerais.

Com isto, dois projetos rodoviários foram se concretizando, e hoje ameaçam a integridade da área indígena: o primeiro, a "Estrada do Progresso", que ligaria a sede municipal ao distrito de Rondolândia e daí a Ji-Paraná, em Rondônia; o segundo, a "Estrada da Integração" ou "Corredor da Exportação", passando pelo Projeto Filinto Müller e seguindo para Apuí, no Amazonas.

Tais estradas, antes de tudo, são defendidas - e definidas - como autênticas bandeiras ideológicas. Não parece irrelevante, neste sentido, o fato de suas denominações - o Progresso e a Integração - coincidirem justamente com as palavras de ordem que, desde a ditadura militar, vêm impulsionando a expansão capitalista na Amazônia, que tem resultado na sua ocupação predatória e no saque criminoso dos seus recursos naturais. Acobertados por estes chavões, reúnem-se habitualmente setores políticos, empresariais e inclusive militares, para os quais os direitos indígenas e as campanhas ambientais obstaculizam o dito desenvolvimento do país.

Daí que em Aripuanã tenha surgido uma comissão48 intitulada "Pró-abertura do Corredor de Exportação", que não se cansa de propagandear que a área indígena Arara iria "afogar" o Município, uma vez que inviabilizaria o escoamento da produção e a interligação com outros municípios. E com o objetivo de barrar a demarcação das terras dos Arara, que teve início em fins de 1994 após a concorrência pública vencida pela firma Ceplan, tal comissão fosse buscar a intervenção dos governos estadual e federal e, pelo que se sabe, do próprio Comando do Exército sediado em Cuiabá. Além de acirrar os ânimos, com boatos e promessas infundadas, de maneira a jogar a população contra os índios Arara. Durma-se com um barulho desses!

Em meio a tudo isto, muito embora desassossegadas, as famílias Arara vão reconstruindo suas vidas no rio Branco 49 . Nem vencidos nem vencedores, pois a história não tem aqui seu ponto final.

\section{Referências}

ARNAUD, Expedito; CORTEZ, Roberto. “Aripuanã: considerações preliminares”. Acta Amazônica, 6 (4): 11-31, 1976.

BARRETO FILHO, Henyo Trindade. Tapebas, Tapebanos e Pernas-de-Pau de Caucaia, Ceará: Da etnogênese como processo social e luta simbólica. Série Antropologia, 165: s/d.

CARNEIRO DA CUNHA, Manuela. Critérios de indianidade ou as lições de antropofagia. Folha de São Paulo, 12/01/1981, p. 3 (seção Tendências e Debates).

${ }^{48}$ Esta comissão foi capitaneada pelo vereador Altamiro Girardi, pelo chefe de gabinete da Prefeitura Alberto da Veiga Kaipper e pelo secretário de Obras Edmundo da Rosa.

49 Ver Lourdes Christ (1995), para uma pequena descrição da vida cotidiana dos Arara já aldeados na área do rio Branco. 
CARNEIRO DA CUNHA, Manuela. O futuro da questão indígena. Estudos avançados, 8 (20): 121-136, 1994.

CHRIST, Lourdes. "Arara do Rio Branco: Saiu finalmente a demarcação”. Porantim, edição janeiro/março, p. 5 .

CIMI - Conselho Indigenista Missionário (Lourdes Christ). Lista do Povo Arara. Aripuanã, datilo, 1988.

CIMI - Conselho Indigenista Missionário (Lourdes Christ). Levantamento do povo Arara em Manaus. Aripuanã, datilo, 1988b.

CIMI - Conselho Indigenista Missionário (Lourdes Christ). Relatório - Povo indígena Arara. Aripuanã, datilo, 1991.

CIMI - Conselho Indigenista Missionário (Lourdes Christ). História de perseguição e ameaças de morte ao povo indígena Arara. Aripuanã, datilo, 1992a.

CIMI - Conselho Indigenista Missionário (Lourdes Christ). Relatório - Povo indígena Arara do Rio Branco. Aripuanã, datilo, 1992b.

CIMI - Conselho Indigenista Missionário (Lourdes Christ). Povo indígena Arara do Rio Branco reconquista o seu território tradicional. Aripuanã, datilo, 1992c.

CIMI - Conselho Indigenista Missionário (Lourdes Christ). Relatório de reunião na Câmara Municipal de Aripuanã. Aripuanã, datilo, 1992d.

CIMI - Conselho Indigenista Missionário (Lourdes Christ). Relato sobre as Estradas Progresso e Corredor de Exportação ou Estrada da Integração. Aripuanã, datilo, 1994 .

DAL POZ, João. "Laudo histórico-antropológico”. In: MALDI, D. (org.). Direitos Indígenas e Antropologia: Laudos Periciais em Mato Grosso. Cuiabá: EdUFMT, 1994. pp. 11-95.

DAL POZ, João. O Real e os Índios. Folha do Estado. Cuiabá, edição de 21 de junho, 1995. p. 8.

DAMATTA, Roberto. Relativizando: uma introdução à antropologia social. Petrópolis: Vozes, 1981.

DIÁRIO DE CUIABÁ. "Invasores atacam índios na região norte do Estado”. Cuiabá, 21/11/1987.

FERNANDES, Florestan. 1 "Os Tupi e a Reação Tribal à Conquista”. In: Investigação Etnológica no Brasil e Outros Ensaios. Petrópolis: Vozes, 1975. pp. 11-32.

FERREIRA, Joaquim Alves. 1905 "Notícia sobre os Indios de Matto-Grosso dada em officio de 2 de dezembro de 1848 ao Ministro e Secretario d'Estado dos Negocios do Imperio, pelo Director Geral dos Indios da então Provincia”. O Archivo, Ano I, vol. 2: 79-96, Cuyabá.

GUILHON, Agesiláo Carvalho. 1919 Relatório sobre a situação actual de algumas tribus da região. Rio Aripuanã, 2 de março de 1919, datilo. (Museu do Índio/Sedoc, Filme 32 Planilha 389).

HARGREAVES, Inês. “Grileiros ameaçam a AI Arara Beiradão”. Jornal da Manhã, São Paulo, edição de 12 de outubro, 1989.

HEBINCK, Júlio; VITTE, Júlio. Relatório de uma missão de "Desobriga” realizada entre 27 de abril a 15 de maio de 1971, Manaus, 25 de maio de 1971, datilo. 
HUGO, Vítor. Desbravadores. Vol. 2. São Paulo: Missão Salesiana de Humaitá, 1959

JORNAL DO DIA. "Invasores fortemente armados atacam índios na região de Aripuanã”, Cuiabá, 22/11/1987.

JORNAL DO DIA. "Delegado de polícia de Aripuanã comandou ataque aos índios Arara”. Cuiabá, 24/11/1987.

LAGO, Francisco Baymado. Ofício ao Inspector do Serviço de Protecção aos Indios no Estado do Amazonas (30 de junho de 1919). Arquivos do SPI, ms. (Museu do Índio/Sedoc, Filme 32 Planilha 389).

LÉVI-STRAUSS, Claude. "Raça e História”. In: Antropologia Estrutural Dois. Rio de Janeiro: Tempo Brasileiro, 1976. pp. 328-366.

MALINOWSKI, Bronislaw. Argonautas do Pacífico Ocidental. São Paulo: Abril Cultural (Coleção Os Pensadores), 1984.

MALTHEZO, João. A história de Manoel Caetano. Aripuanã: Sindicato de Trabalhadores Rurais, datilo, 1990a.

MALTHEZO, João. História de Jerônimo Marinho e índios Arara. Aripuanã: Sindicato de Trabalhadores Rurais, datilo, 199ob.

MENÉNDEZ, Miguel. Uma contribuição para a etno-história da área TapajósMadeira. Revista do Museu Paulista, 28: 289-388, 1981/82.

MONTEIRO, John. "O desafio da história indígena no Brasil". In: LOPES DA SILVA, A.; GRUPIONI, L. D. B.: A temática indígena na escola. Brasília: MEC/MARI/UNESCO, 1995. pp. 221-228.

NIMUENDAJU, Curt. Mapa Etno-Histórico. Rio de Janeiro: IBGE/Pró- Memória, 1981.

PORANTIM. "Indígenas são quistos para Protásio”, junho/julho, 1980, p. 6.

PORANTIM. "AraraMT: Uma comunidade no exílio", julho/agosto, 1988, p. 14.

PORANTIM. "Arara do Beiradão: A reconquista da terra invadida”, novembro, 1992, p. 5 .

PINHEIRO, Geraldo. "A aldeia indígena de Sapucaia-Oroca". Revista de Antropologia, 17/20 (1): 49-58, 1969-72.

PRADO, Eduardo Barros. La atraccion de la selva. Buenos Aires: Peuser, 1959.

RIBEIRO, Darcy. Antropologia ou a teoria do bombardeio de Berlim" (Entrevista a Edilson Martins). Encontros com a Civilização Brasileira, 12: 81-100, 1979.

RIBEIRO, Darcy. Os índios e a civilização. Petrópolis: Vozes, 1982.

RONDON, Cândido Mariano da Silva. Conferências realizadas nos dias 5, 7 e 9 de outubro de 1915 no Theatro Phenix do Rio de Janeiro. Rio de Janeiro: Typ. Jornal do Commercio (Comissão Rondon, publicação 42), 1916.

RONDON DE SÁ, Policarpio Mestrinho. Ofício ao senador Jonas Pinheiro, 16 de janeiro de 1995 .

SÁ, Sheila M. Guimarães de. Identificação da terra indígena Arara do Rio Branco

(Aripuanã - MT). FUNAI, Museu do Indio, datilo, 1991. 
SANTOS, José Augusto Mafra dos. Os órfãos de uma nação. FUNAI $/ 2^{\circ}$ Superintendência Regional, datilo. 1988

SANTOS, Vera Lopes dos. Relatório de identificação da Área Indígena Arara Beiradão. FUNAI $/ 2^{\circ}$ Superintendência Regional, datilo, 1987.

SILVA, Dêidi Luci da. Relatório de viagem à Área Indígena Arara-Beiradão. FUNAI $/ 2^{\circ}$ Superintendência Regional, datilo, 1988.

SOBRINHO, Sebastião Otoni de Carvalho. Relatório $n^{0} 1 / 71$ (ao Governador do Estado de Mato Grosso, José Manoel Fontanillas Fragelli). Cuiabá, 21 de junho de 1971, datilo.

SPI - Inspetoria do Amazonas e Acre. Relatório da Inspectoria referente ao ano de 1924 (inspetor Bento Martins Pereira Lemos). Manaus, datilo., 140 p. (Arquivos do SPI: Museu do Indio/Sedoc, Filme 33 Planilha 396), 1925.

SPI - Inspetoria do Amazonas e Acre. Relatório da Inspectoria referente ao ano de 1928 (inspetor Bento Martins Pereira Lemos). Manaus, datilo., 214 p. (Museu do Índio /Sedoc, Filme 340 Planilha 53), 1929.

SPI - Inspetoria do Amazonas e Acre. Relatório da Inspectoria referente ao ano de 1941 (inspetor Carlos Eugenio Chauvin). Manaus, datilo., 280 p. (Museu do Indio/Sedoc, Filme 340 Planilha 56).

VALDEZ, Manuel. Levantamento dos índios Arara no município de Aripuanã MT. Equipe de Pastoral Indigenista da Diocese de Ji-Paraná, datilo., 1984.

VALDEZ, Manuel. Renovação de pedido de área para os índios Araras das bacias dos rios Aripuanã e Guariba. CIMI - Regional Rondônia, datilo., 1985.

VALDEZ, Manuel. Novos contactos com índios Arara e seringueiros do Aripuanã. CIMI - Regional Rondônia, datilo., 1986 


\section{Apêndice 1 Vocabulários}

Os vocabulários abaixo foram recolhidos por Hugo (1959) é por uma equipe do CIMI (VALDEZ, 1984). Embora não tenham sido submetidos, até onde sei, a qualquer análise linguística, parece-me que algumas indicações relevantes poderiam ser extraídas de um exame tão-somente preliminar. É o que se segue.

Os vocábulos para os Arara do Guariba (Lista B), com poucas exceções, configuram uma língua da família Tupi-Mondé, à qual pertencem os Cinta Larga, Zoró, Suruí, Gavião e Aruá. Não há mais que diferenças de notação para as palavras respectivas em Cinta Larga, afora os termos para banana, cobra e farinha, que desconheço, e a tradução para macaco coatá, alimé, que não é empregada porestes, mas pelos Suruí.

Quanto às listagens para os "índios Vela" (Lista A) e "Arara do Aripuanã" (Lista O), que são os atuais Arara do rio Branco, descontados os equívocos fonéticos das transcrições, verifica-se uma absoluta identidade entre todos os vocábulos comuns a ambas. Por sua vez, estas diferem bastante das línguas Tupi-Mondé, exceto em poucas palavras (chuva, dente, onça, pedra, jacu, peixe, pés, roçado, rato, serra, sol, veado). Trata-se evidentemente de uma língua pertencente ao tronco Tupi. Muito embora haja consultado vários vocabulários recolhidos entre grupos indígenas da região (Mura, Ntogapid, Matanawi, Kawahib etc.), não encontrei, até agora, quaisquer correspondências significativas.

\section{A. LISTA DE VOCÁBULOS DA GÍRIA DOS ÍNDIOS CIVILIZADOS DE "TRÊS TOMBOS" (RIO} BRANÇO, AFLUENTE DO ALTO RIO ARIPUANÃ, MT)

Este vocabulário foi coletado pelo missionário salesiano Vítor Hugo, em sua viagem aos rios Aripuanã e Branco em 1958 Junto aos "índios Vela" (HUGO, 1959, Apêndice 42, p. 435). Não dispondo dos signos ortográficos utilizados na publicação original, para esta transcrição procedi a ligeiras alterações na notação dos vocábulos que, espero, não impossibilitem sua comparação com as demais.

Água: ade
Alma: iuppit
Anta: mundiê
Arco: brexoe
Bonito: ikei
Braço: pike
Cabeça: numbá
Cabelo: mmbabw
Cachoeira: toerceros
Cão: wetwce
Caranguejo: culwa
Casa (= maloca): miab
Cinturão: pretina (7)
Dedos: mpai
Dentes: noi
Espingarda: breká
Flecha: mmbai
Flechar: titoé
Fotografia: numinhã

Água: ade

Arco: brexoe

Cabeça: numbá

Cachoeira: toerceros

Cão: wetwce

Caranguejo: culwa

Cinturão: pretina (7)

Dedos: mpai

Espingarda: breká

Fotografia: numinhã

\author{
Galinha: craéi \\ Homem: pipe \\ Jabuti: siberce \\ Macaco barrigudo: psá \\ Macaco preto: quené \\ Matar: sêgue \\ Menina: kã \\ Menino: mecnã, baiáh \\ Milho: viá \\ Mulher: wira, huai (?) \\ Nariz: núnha \\ Nome (da tribo): Camí(u)aï \\ Olhos: capide \\ Orelha: mbechade \\ Peixe: uribw \\ Pernas: moeke \\ Queixada: bod \\ Terçado: sirê \\ Vá embora: figá
}




\section{B. VOCABULÁRIO ARARA DO RIO GUARIBA}

Estes vocábulos foram colhidos pelos agentes do CIMI que, nos meses de setembro e outubro de 1984, fizeram um levantamento da população Arara. A informante, no caso, foi Nazaré Arara que então residia na cidade de Aripuanã (VALDEZ, 1984: 12). Acrescentei à listagem a palavra tamoáp e as ortografias entre parênteses, que ouvi da mesma informante.

Anta: wuasá
Arara: awala
Banana: bubuka
Cachorro: awulú
Cobra: subá
Dente: nuin
Farinha: muiú
Galinha: aranha
Gente civilizada: indjarei (zadey)
Jacamim: tamali
Jacaré: wuaú

Jacu: tamoáp

Macaco barrigudo: masaikurê

Macaco: coatã arimê (alimé)

Mutum: wakuia (wakuy)

Nambu azul: wuanha

Onça: beku

Pacu: burikabé

Porco grande: bebé

Porquinho: bibekut

Veado: tiap

\section{VOCABULÁRIO DOS ARARA DO ARIPUANÃ}

Para este vocabulário, relativo aos índios Arara do rio Branco, elaborado pela equipe do CIMI acima referida (VALDEZ, 1984: 13-16), os informantes foram: Rodrigo Vela (então com 42 anos), João (de Ariquemes, 44 anos) e Guilhermina (80 anos). Os símbolos utilizados guardariam os mesmos valores que os atribuídos na ortografia do português falado no Brasil (exceto as vogais central alta não-arredondada $\mathrm{e}$ central média não arredondada $\partial$ e a consoante nasal velar sonora $\mathrm{D}$ ).

Abacaxi azedo: arurã

Abelha jandaira: arã

Abelhinha: pitik Água: adete Algodão: britap Andarligeiro: kerip Anta: muinhe

Aranha (que morde): picho Aranha branca: pichombá Arapuá: abeka Arara: kurot Arco: brichak Arraia: uribidak Avó (nome?): tanha Avô (nome?): marina Banana: kuenã Banana (tipo): ukuã Barba: futá awa

Batata doce: mbatin Bicho: atonha Boca: mbeisau

Bolo de beiju: tukure Braço: pika

Brinco (de madeira): kunhanzi Cabeça: mkubap Cabelo: mbiap Caititu: pirã Cará: tubuia Caranguejo: pichubá Castanha: mowi
Castanheira: mowip Céu: arumbei

Chicha de patauá: arupetak Chorar: howá

Chuva: doi

Cintura: kupike

Cipo (para cesto): minhombá

Cobra: mundopá

Coco: paai

Colar: mukait

Comer: praiz

Comida boa: lakat

Costelas: dukumbé

Cuia: tiop

Cutia: pspo

Dedo da mão: piat

Dedos do pé: upe

Dentes: nain

Doendo (vb. Doer): kumadzei Dor: iai

Dormir: nuset

Envira: popé

Espingarda: breká

Esteira de palha: sipe

Estômago: orep

Estrela: setka

Fechar: uripte

Fígado: nupiton

Flecha: baik

Fogo: rekat 


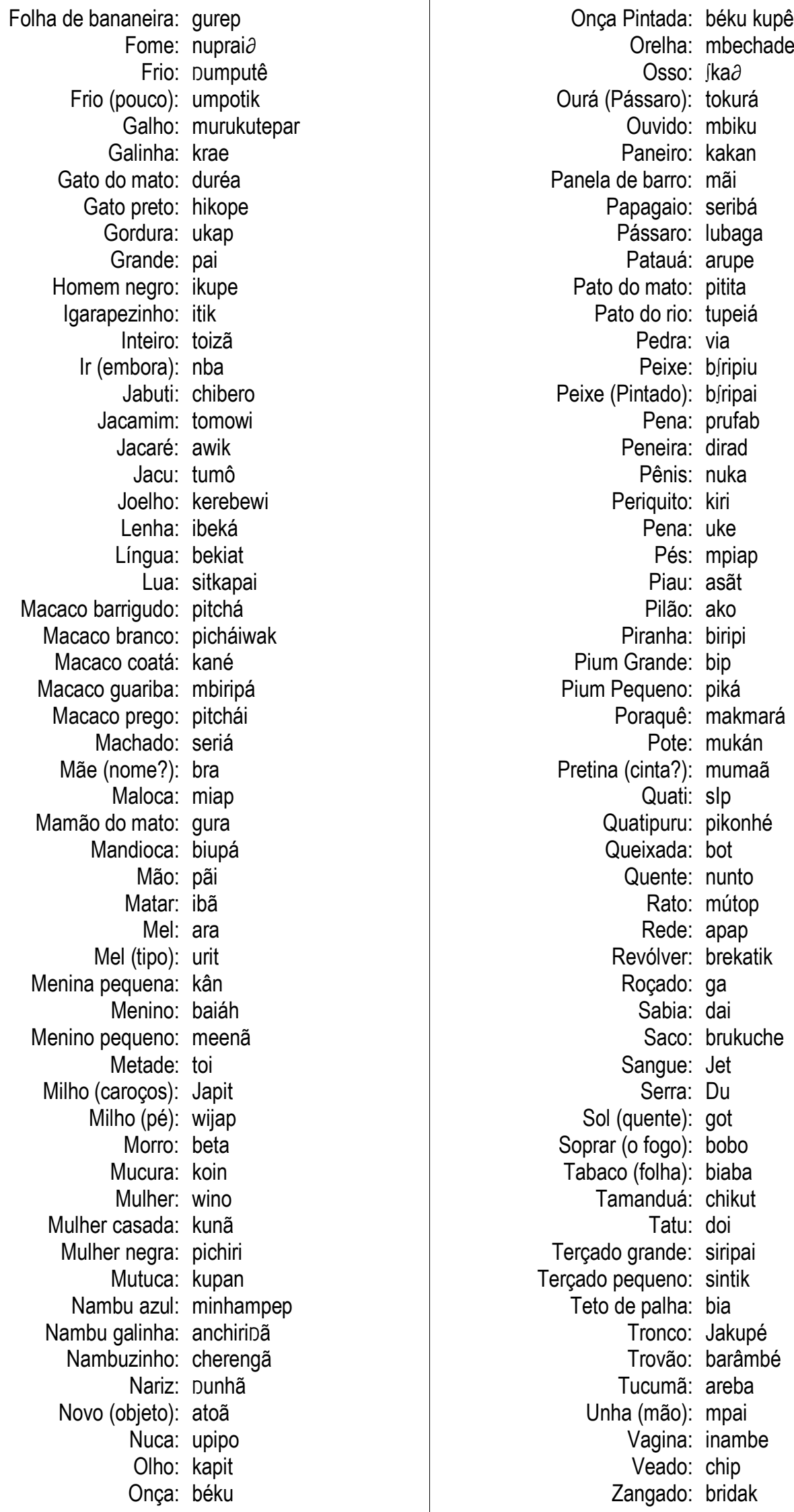




\section{Apêndice 2 \\ Dados Demográficos}

No quadro a seguir estão computadas as informações censitárias presentes em vários relatórios. Devo advertir, desde logo, que os autores incluíram tanto informações diretas quanto de terceiros e, também, que nem sempre procuraram ou puderam relacionar a população total dos Arara. Os dados de Valdez (1984, 1986), por exemplo, são quase exclusivamente das famílias Arara visitadas pela equipe do CIMI - Rondônia nos rios Branco e Guariba e nas cidades de Ariquemes, Aripuanã e Matá-matá. Já os do CIMI (1988), são informações orais, fornecidas pelos familiares que moravam em Aripuanã, bem como das famílias visitadas em Manaus pela irmã Lourdes Christ. Já os dados de Santos (1987) refletem o levantamento realizado pelo primeiro GT da FUNAI, sendo o que melhor retrata a população do Guariba. Por fim, os de Sá (1991), também de um GT da FUNAI, sistematizam os dados anteriores e acrescentam os relativos à cidade de Aripuanã, obtidos pela autora.

Não considerei, nos totais para cada localidade, a distinção entre Arara do Guariba e do Rio Branco, e neles estão incluídos também alguns indivíduos nãoíndios (cerca de 19, por exemplo, nos dados de SANTOS, 1987), em geral relacionados aos Arara por matrimônio. As colocações ao longo do rio Aripuanã estão assinaladas por A, enquanto as do Guariba, por G. E por fim, rio Aripuanã e rio Guariba correspondem aos totais ao longo dos respectivos rios, na medida em que o autor não discrimina a população parcial por localidade.

Olhando para este quadro demográfico, um único, porém significativo, comentário: os números sinalizam um expressivo deslocamento desta população em direção às cidades, que nesta segunda metade da década de 80 parece buscar moradia em Aripuanã, Manaus ou Porto Velho, abandonando ou sendo expulsa das margens dos rios.

\begin{tabular}{|c|c|c|c|c|c|}
\hline & $\begin{array}{c}\text { Valdez } \\
1984\end{array}$ & $\begin{array}{c}\text { Valdez } \\
1986\end{array}$ & $\begin{array}{c}\text { Santos } \\
1987\end{array}$ & $\begin{array}{c}\text { CIMI } \\
1988\end{array}$ & $\begin{array}{c}\text { Sá } \\
1991\end{array}$ \\
\hline A - rio Aripuanã & & & & 53 & 38 \\
\hline A - Boca do Roosevelt & & & 5 & & \\
\hline A - Campo Grande & 12 & 12 & 6 & & \\
\hline A -Boca do Piranha & 6 & 6 & 7 & & \\
\hline A - Boca do Pacutinga & 19 & 21 & 10 & & \\
\hline A - Bom Sucesso & 19 & 19 & 22 & & \\
\hline A - Boca do rio Branco & 4 & & & & \\
\hline G - rio Guariba & (5 fam.) & 10 & & & 35 \\
\hline $\mathrm{G}$ - Esperancinha & & & 32 & & \\
\hline G - Fortaleza & & & 6 & & \\
\hline $\mathrm{G}$ - Vista Alegre & & & 3 & & \\
\hline G - Biquadá & & & 7 & & \\
\hline G - Pajurá & & & 6 & & \\
\hline Aripuanã (MT) & 25 & 25 & 46 & 27 & 90 \\
\hline Cuiabá (MT) & & & & 8 & 1 \\
\hline Matá-matá (AM) & 3 & 5 & 9 & 30 & 17 \\
\hline Manaus (AM) & & 1 & 3 & 106 & 15 \\
\hline \multicolumn{6}{|l|}{ Prainha (AM) } \\
\hline Humaitá (AM) & & 1 & & & 17 \\
\hline Ariquemes (RO) & 8 & & & 12 & \\
\hline Porto Velho (RO) & & 1 & 1 & 20 & \\
\hline Totais & 96 & 101 & 163 & 256 & 213 \\
\hline
\end{tabular}




\section{Apêndice 3}

Mapas

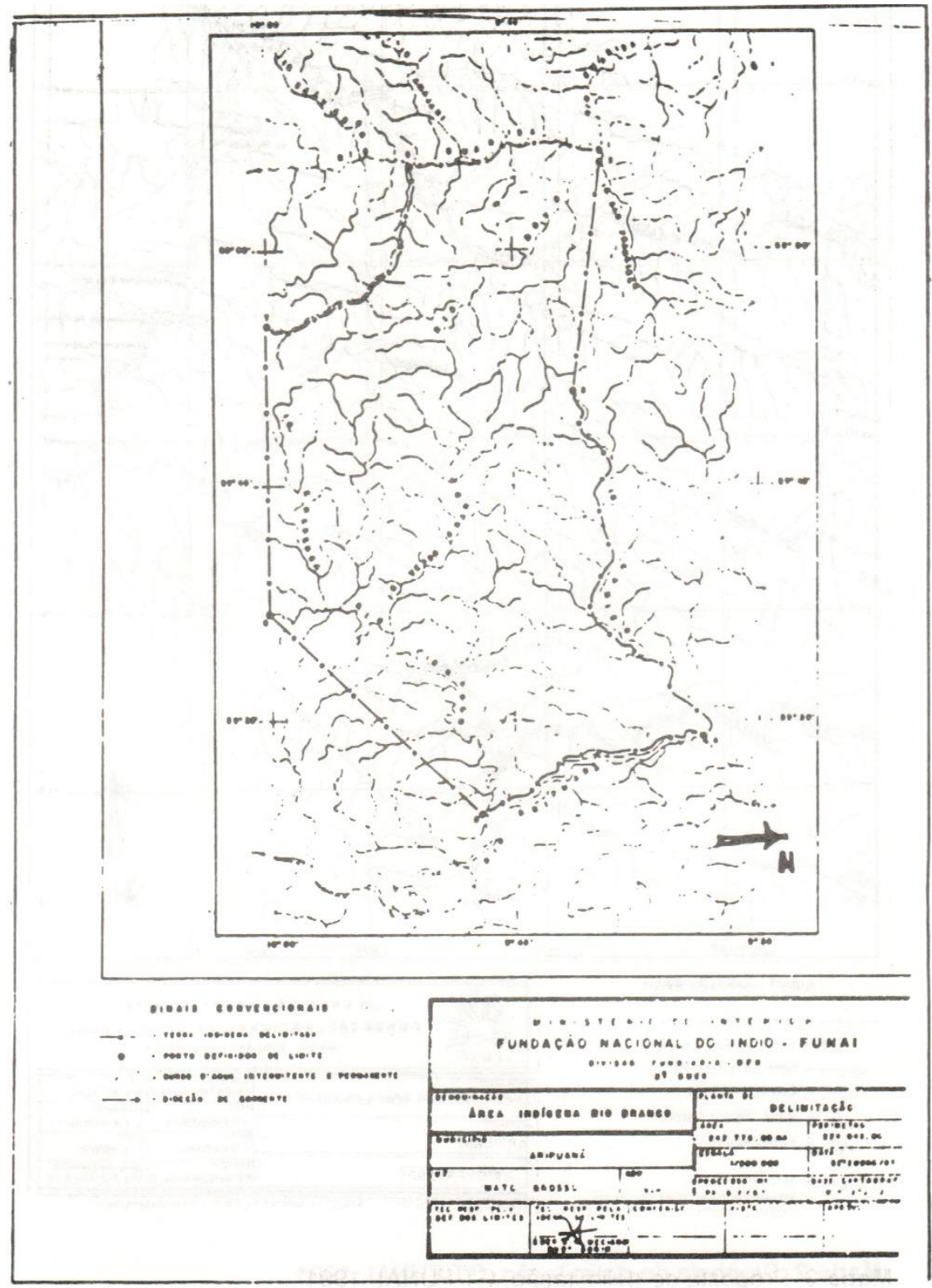

Mapa 1: Proposta de interdição, GT FUNAI, 1987. Quadro reproduzido do original 


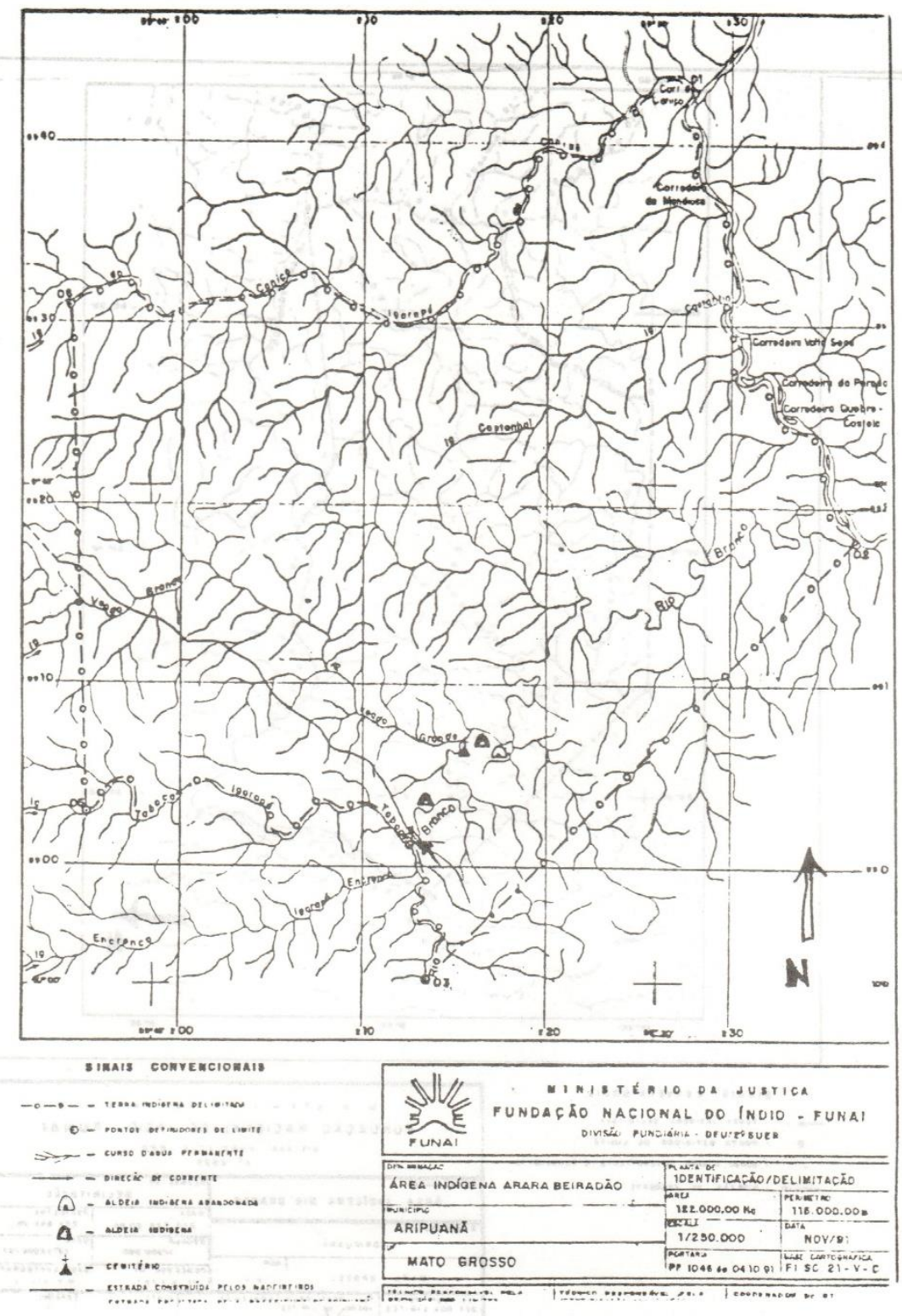

Mapa 2: Proposta de delimitação, GT FUNAI, 1991. Quadro reproduzido do original 